\title{
Chapter 11 \\ The Role of Urban Planning and Landscape Tools Concerning Flash Flood Risk Reduction Within Arid and Semiarid Regions
}

\author{
Karim I. Abdrabo, Sameh A. Kantosh, Mohamed Saber, \\ Tetsuya Sumi, Dina Elleithy, Omar M. Habiba, and Bahaa Alboshy
}

\begin{abstract}
This chapter highlights some substantial questions inquired by researchers to comprehend the flood risks (FRs) that occur in their cities as follows: (1) What is the impact of flooding on urban areas? (2) what effect does urbanization have on FR? (3) What are the existing nonstructural and structural mitigation measures for urban flooding? and (4) What is the role of urban planning and landscape tools in flood risk reduction (FRR) for cities as well as their inhabitants? The main messages in this chapter could be summarized as follows:
\end{abstract}

\footnotetext{
K. I. Abdrabo ( $₫)$

Faculty of Urban and Regional Planning, Cairo University, Giza 12613, Egypt

e-mail: m.karim.ibrahim@cu.edu.eg

K. I. Abdrabo · D. Elleithy

Department of Urban Management, Graduate School of Engineering, Kyoto University,

Kyoto 615-8245, Japan

e-mail: Dina.elleithy@eng.asu.edu.eg
}

S. A. Kantosh · M. Saber · T. Sumi - O. M. Habiba

Disaster Prevention Research Institute (DPRI), Kyoto University, Kyoto 611-0011, Japan

e-mail: kantoush.samehahmed.2n@kyoto-u.ac.jp

M. Saber

e-mail: mohamedmd.saber.3u@kyoto-u.ac.jp

T. Sumi

e-mail: sumi.tetsuya.2s@kyoto-u.ac.jp

O. M. Habiba

e-mail: habiba.omarmohamedali.8s@kyoto-u.ac.jp

D. Elleithy

Irrigation and Hydraulics, Department of Civil Engineering, Faculty of Engineering, Ain Shams University, Cairo 11535, Egypt

B. Alboshy

Architectural Engineering Department, Faculty of Engineering, Tanta University, Tanta 31733, Egypt

e-mail: bahaa.elboshi@f-eng.tanta.edu.eg

(C) The Author(s) 2022

T. Sumi et al. (eds.), Wadi Flash Floods, Natural Disaster Science and Mitigation

Engineering: DPRI Reports, https://doi.org/10.1007/978-981-16-2904-4_11 
(1) Comprehension of both the sources and types of flooding is vital if proper FRR measures are to be determined, (2) Unplanned urban growth could seriously put lives and properties at high risk (3) Land use planning and regulation, and Sustainable infrastructure for stormwater management through landscape architecture are fundamental measures for future FRR (4) The application of the urban planning approach for FRR in arid and semiarid regions has not yet received adequate attention and facing many challenges for its implementation, and finally (5) the combination of structural and nonstructural mitigation measures in spatial planning could be much more effective than using one type of measure alone.

Keywords Flash flood - Urban flood - Urban planning • Landscape • Flood risk reduction - Arid and semiarid regions • Urbanization - Mitigation measures

\subsection{Introduction}

The United Nations (UN) indicated that $43 \%$ of natural disasters worldwide, from 1995 to 2015 , were caused by floods, which impacted approximately $56 \%$ of all people affected by natural disasters and caused casualties for approximately $26 \%$ of them (Bertilsson et al. 2019). High losses in both lives and the economy will decrease the capability of communities' sustainability.

Rapid urban expansion, economic development and population growth significantly contribute to increasing the area exposed to natural hazards, especially floods (Kaspersen et al. 2017; Mojaddadi et al. 2017). Consequently, in the future, the environment, people, and property will experience persistent risks. Exposure is one of the three main components of FR and has been defined as the assets that could be affected due to their locations in flood-prone areas (UNISDR 2017). The other two components of FR are hazard and vulnerability (Len et al. 2018). If one of these elements is missing, the flood risk is not defined. The flood hazard is related to the potential danger that the natural phenomenon presents, which is inherent to the event itself; in this study, the hazards are characterized by inundation scenarios (Schanze 2006). Vulnerability is defined as a propensity or disposition to being adversely affected by an event. This definition includes the characteristics of a person or a group, and the characteristics of their situations, that influence their capacity to anticipate, cope with, resist, and recover from the adverse effects of physical events (Cardona et al. 2012). Decision makers need to be supported to take appropriate measures aimed at reducing flood risk in an effective and sustainable manner (Fernandez et al. 2016).

However, the main problem facing FRR mitigation measure processes involves the limitations of structural "hard" measures (i.e., storm surge barriers and floodwalls) against unexpected flooding events, despite the modernization of flood prevention measures (Kang et al. 2009). Moreover, "soft" strategies (i.e., building codes, land use and nature-based measures) can play critical roles in reducing FR (Du et al. 2020). Additionally, these "soft" measures do not require extensive 
investment in hard-engineered infrastructures, as structural measures typically do, but instead rely instead on a good understanding of flood hazards and adequate forecasting systems.

Spatial planning is increasingly considered an important tool for FRR. Its main advantage is its capability of regulating the use of space for the long term. Appropriate land use allocation can minimize or even prevent exposure to natural hazards in current and future situations. Coordinated regulations are needed to incorporate disaster risk reduction strategies in spatial planning (Sutanta et al. 2010). Flood risk management and river ecosystem conservation have not been traditionally considered components of the urban planning process. This fact is due in large part to the division of academic fields. Those who deal with flooding and water quality are trained in river engineering, hydrology, geology, chemistry, or geophysics, whereas urban planners are most likely trained in architecture, traditional landscape, road engineering or social sciences. This missing or insufficient link to water management can be considered a fundamental flaw in the urban planning system to date (Huang and Shen 2019).

Accordingly, this chapter aims to shed light on the most common spatial planning tools for FRR, which have become important tools used by city planners and decision makers to manage FR. The chapter begins with an understanding of the types and sources of flooding, followed by descriptions of the flooding impacts, especially in urbanized areas. Then, descriptions and comparisons of different types of mitigation measures are provided. The next section describes the significant role of spatial planning tools in FRR. The final section provides conclusions.

\subsubsection{Flood Causes, Classifications, and Types}

Urban floods are a consequence of compounding hydrological and meteorological extremes in addition to human activities (Jha et al. 2012), as shown in Fig. 11.1. For example, extreme precipitation and flows and informal urban sprawl in floodplains increase urban flood risk. Usually, people moving from rural to urban areas or within urban areas settle in areas prone to floods. The absence of flood countermeasures may cause an increase in inhabitants' vulnerability in these areas. Land use changes can reduce the permeability of soils, which increases surface runoff and overloads drainage systems; consequently, the flood risk may increase (Jha et al. 2012). Additionally, flood triggers accumulate, which accelerates their impacts. This evolving challenge requires a better understanding of FR and more effective management by policy makers.

Floods are usually classified according to the duration of the flood event and its appearance as follows (Şen 2018):

(1) Long-standing floods: May extend to a week or longer

(2) Short-standing floods or "flash floods": Usually extend to approximately $6 \mathrm{~h}$ or less 


\section{Flood Causes}

\section{The man-made and natural causes of flooding}

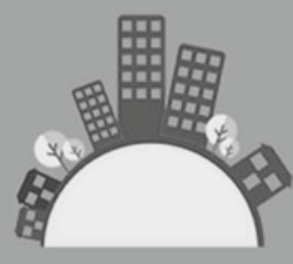

Increased Urbanisation

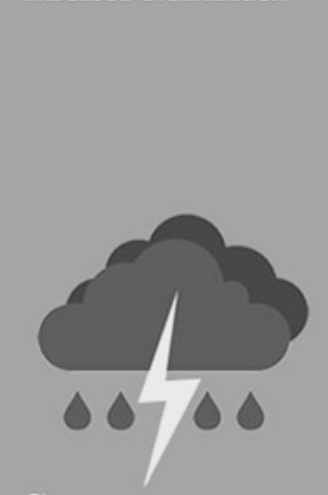

Storms

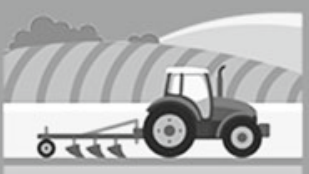

Bad Farming Practice

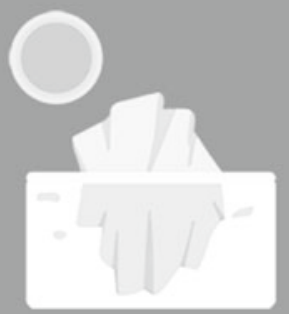

Ice and Snow Melting

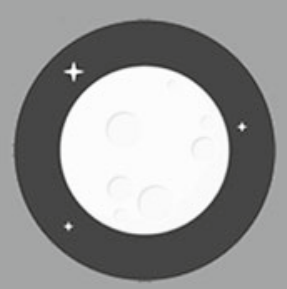

Moon Phases

Fig. 11.1 Flood causes (man-made and natural causes) (Modified from: Flood infographic: types, causes and cost of flooding 2016)

In contrast, floods are also classified by their appearances into four types as follows (Șen 2018):

(1) River or stream floods

(2) Urban floods that occur in creeks or streets in urban areas

(3) Dry water-collector floods such as mountain sides and slopes

(4) Coastal floods caused by low atmospheric pressure on the sea surface

Below, Fig. 11.2 and Table 11.1 show the different types of floods. The causes and durations of each flood type are presented. 


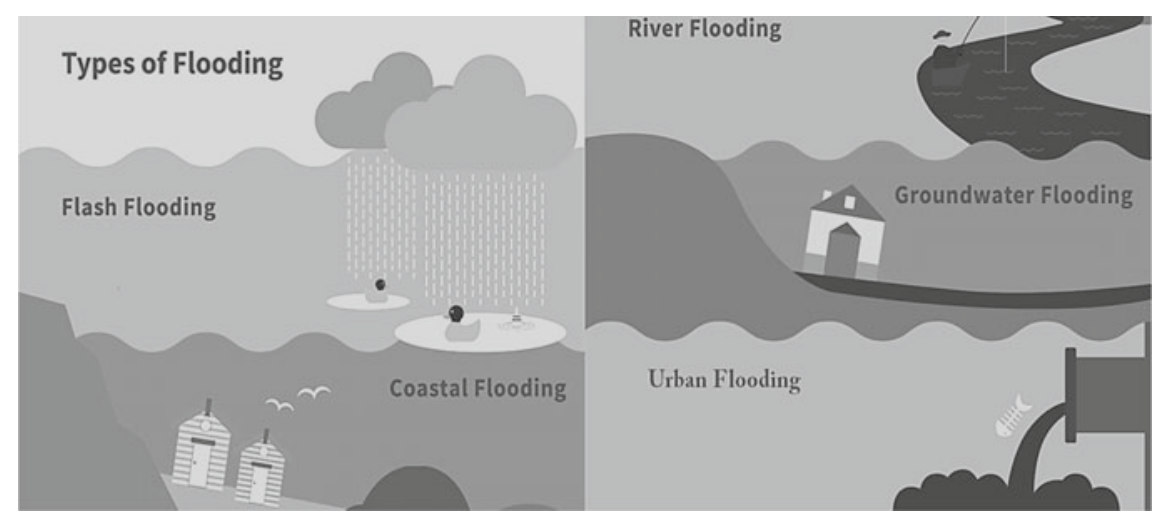

Fig. 11.2 The different types of floods (Modified from: Types of Flooding in the UK 2018)

\subsubsection{Urbanization and Flood Risk (FR) Impact}

Floods are one of the most frequent and devastating natural disasters worldwide, causing significant economic damage and loss of life. Accordingly, urban flooding has become very costly and difficult to manage, especially in developing countries that suffer from high concentrations of people and property. In addition to the direct impact of floods, floods have long-term indirect consequences, such as loss of educational opportunities, disease, and reduced nutrition, which may impede the achievement of developmental goals.

Several types of floods can occur in urban areas, such as river, coastal, pluvial and groundwater floods. In urban areas, there is a shortage of available areas that can be used for excessive water storage. High rainfall intensities and lack of adequate capacities for drainage systems can cause flooding in urban areas. Continuous and extended urban expansion reduces the permeability of land soil, increasing the runoff and flooding risk. Deficient or inappropriate land use planning is mainly responsible for increasing the urban FR, while many urban areas are facing the challenges of rising populations and high demands for newly developed areas (Abdrabo et al. 2020; Saber et al. 2020). However, while existing laws and regulations control the construction of new infrastructure and different building types, there is often no enforcement in place to ensure proper application because of different factors, such as economic factors, political factors, capacity constraints or resource constraints. Consequently, water flow paths in urban areas can be obstructed, causing floods (Jha et al. 2012).

Urbanization is accompanied by changes in natural landscapes and changes in land use and land cover (LULC), which increase impermeable areas and runoff, reduce infiltration, and change the frequency of flood incidences, as shown in Fig. 11.3. Hollis, in 1975, anticipated that the incidence of floods might increase up to ten times due to extensive urbanization, while for floods of 100-year return 
Table 11.1 The different types of floods and their causes and duration

\begin{tabular}{|c|c|c|c|}
\hline \multirow[t]{2}{*}{ Flooding type } & \multicolumn{2}{|l|}{ Causes } & \multirow[t]{2}{*}{ Period } \\
\hline & Natural & Anthropogenic & \\
\hline Urban flood & $\begin{array}{l}\text { Fluvial } \\
\text { Coastal } \\
\text { Flash } \\
\text { Pluvial } \\
\text { Groundwater }\end{array}$ & $\begin{array}{l}\text { - Inappropriate } \\
\text { drainage and } \\
\text { sewage capacity } \\
\text { for the rainfall } \\
\text { amount } \\
\text { - Lack of land cover } \\
\text { permeability due to } \\
\text { increased } \\
\text { urbanization } \\
\text { - Drainage system } \\
\text { failure and lack of } \\
\text { appropriate } \\
\text { interventions }\end{array}$ & $\begin{array}{l}\text { Various timescales } \\
\text { starting from hours and } \\
\text { extending to days }\end{array}$ \\
\hline Pluvial flood & $\begin{array}{l}\text { Convective, thunderstorms } \\
\text { severe rainfall, breakage of } \\
\text { ice jam glacial lake burst } \\
\text { earthquakes resulting in } \\
\text { landslides }\end{array}$ & $\begin{array}{l}\text { - Land use changes } \\
\text { - Urbanization } \\
\text { - Increase in surface } \\
\text { runoff }\end{array}$ & $\begin{array}{l}\text { Varied periods } \\
\text { depending on existing } \\
\text { conditions }\end{array}$ \\
\hline $\begin{array}{l}\text { Coastal flood } \\
\text { (tsunami, } \\
\text { storm surge) }\end{array}$ & $\begin{array}{l}\text { Earthquakes Submarine } \\
\text { volcaniceruptions } \\
\text { subsidence coastal erosion }\end{array}$ & $\begin{array}{l}\text { - Urban sprawl in } \\
\text { coastal zones } \\
\text { - Damaging of } \\
\text { coastal natural } \\
\text { flora (e.g., } \\
\text { mangroves) }\end{array}$ & $\begin{array}{l}\text { Events usually occur in } \\
\text { short time periods and } \\
\text { may take a long time to } \\
\text { recede }\end{array}$ \\
\hline $\begin{array}{l}\text { Groundwater } \\
\text { flood }\end{array}$ & $\begin{array}{l}\text { High water table level } \\
\text { combined with heavy } \\
\text { rainfall embedded effect }\end{array}$ & $\begin{array}{l}\text { - Development in } \\
\text { low-lying areas } \\
\text { - Interference with } \\
\text { natural aquifers }\end{array}$ & Long durations \\
\hline Flash flood & $\begin{array}{l}\text { Can be caused by river } \\
\text { pluvial or coastal systems; } \\
\text { convective thunderstorms; } \\
\text { glacial lake outburst floods } \\
\text { (GLOFs) }\end{array}$ & $\begin{array}{l}\text { - Sudden failure of } \\
\text { water-retaining } \\
\text { structures } \\
\text { - Inadequate } \\
\text { drainage } \\
\text { infrastructure }\end{array}$ & $\begin{array}{l}\text { Typically, last a few } \\
\text { hours }\end{array}$ \\
\hline
\end{tabular}

Source Data source: Jha et al. 2012

periods or greater, the severity could be doubled if $30 \%$ of roads were paved (Wheater and Evans 2009).

Floods pose a range of threats to human life, health, and well-being. In 2010, reported floods directly caused over 8000 lost lives. While direct deaths from flooding have declined over time as measures to prevent flooding have been employed, the economic loss is growing, particularly in developed countries, as shown in Fig. 11.4.

Unplanned urban growth creates indigent areas that lack suitable residences, services, and infrastructure, making these areas, and especially the children, elderly 
40\% Evapo-Transpiration

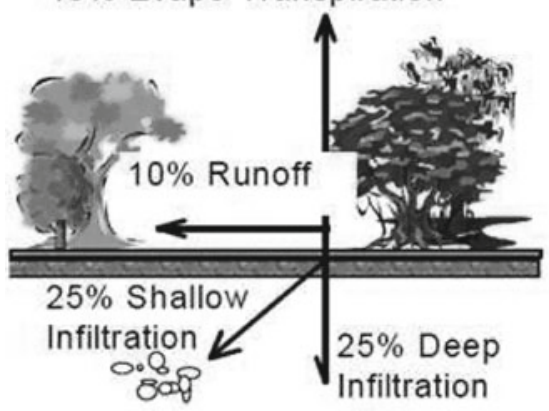

Natural Ground Cover

$35 \%$ Evapo-Transpiration

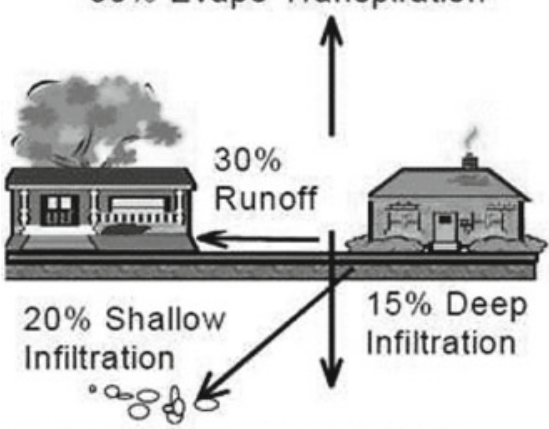

35-50\% Impervious Surface
$38 \%$ Evapo-Transpiration

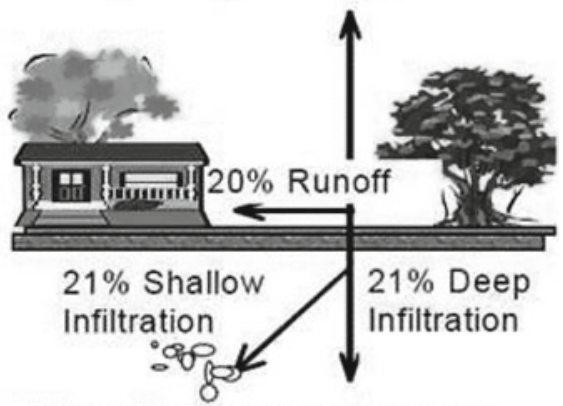

$10-20 \%$ Impervious Surface

$30 \%$ Evapo-Transpiration

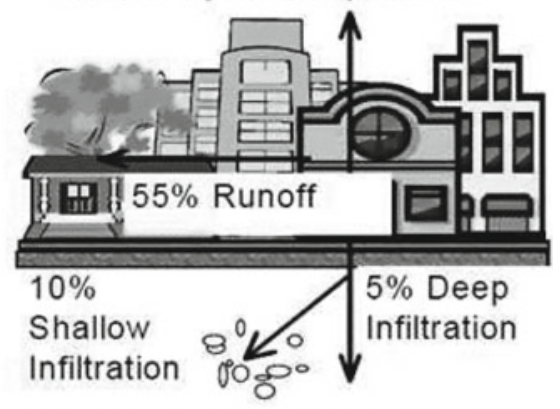

$\mathbf{7 5 - 1 0 0 \% ~ I m p e r v i o u s ~ S u r f a c e ~}$

Fig. 11.3 Urbanization impact on water cycle changes (Modified from: NEMO 2018)
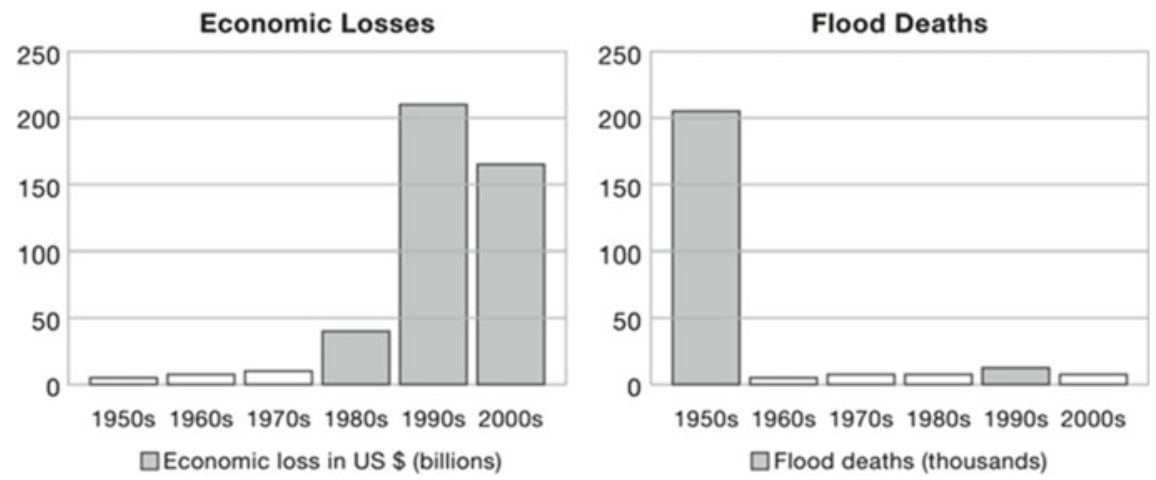

Fig. 11.4 Reported economic losses and deaths resulting from flood events. Source based on EM-DAT/CRED (Different natural disasters on a global scale 2016) 
people, and women who live in them, more vulnerable to floods. The most operative way to manage FR is to embrace an integrated approach that combines structural and nonstructural mitigation measures (Jha et al. 2012). Flooding is the phenomenon with the greatest impact on the human population worldwide, with more than 2.8 billion people affected by floods since 1990 (EM-DAT 2016). However, the effect of flooding is mainly concentrated in the economic sector rather than in losses of lives when compared to other natural disasters, such as earthquakes. A comparison between floods and other types of natural disasters is shown in Fig. 11.5.

Egypt, for instance, is an arid and semiarid Arabian country that suffers from devastating flooding events, with an estimated total economic loss of approximately 1.2 billion USD/year in both the coastal and Nile wadi systems in the period from 1975 to 2014 (Abdel-Fattah et al. 2015). Flash floods in Egypt, although short-lasting, can be enormously harmful and represent a threat to property as well as lives. Most of the viable highways and other significant infrastructures are constructed across wadis. Many factors have pushed people to live in flood-prone areas. Recently, floods have become more frequent, causing fatalities and substantial damage in Egypt (Abdel-Fattah et al. 2015; Mohamed 2019). For example, urban floods in Alexandria have caused severe damage and losses, and the city has shown a lack of resilience in facing several events (Fig. 11.6).

Alexandria faced its worst flooding events on 25 October and 4 November 2015; nearly $60 \%$ of the city was flooded, the flood inundation ranged from 0.5 to $1.0 \mathrm{~m}$, and lowland areas remained affected for up to 15 days. These flooding events occurred due to heavy rainfall of nearly $32 \mathrm{~mm}$; these rainfall events were considered rare and historically significant (Zevenbergen et al. 2017). A recent study published in 2019 investigated extreme rainfall events that caused urban flooding in Alexandria, and the losses caused by these events are shown in Table 11.2 (Elboshy et al. 2019).
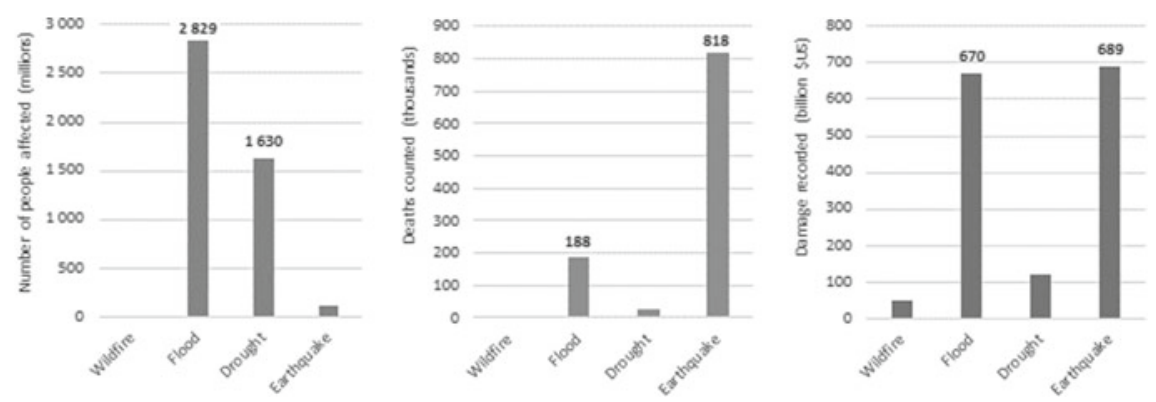

Fig. 11.5 Comparison of the damage caused by different natural disasters on a global scale (Data source: EM-DAT-2016) (Different natural disasters on a global scale 2016) 

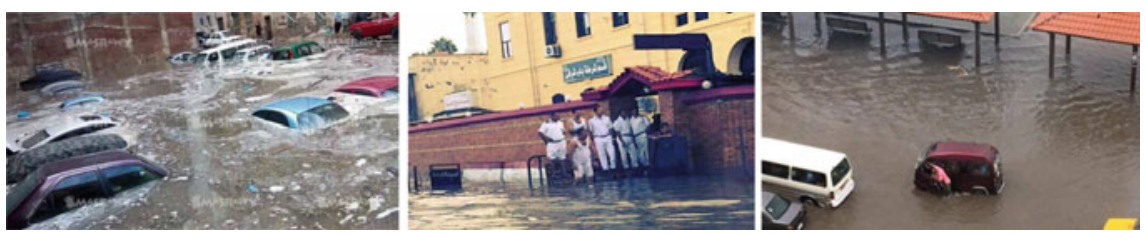

Fig. 11.6 Devasting urban flash floods in Alexandria, Egypt during the 2015 event (Reprinted from: Ashraf Abdalhameed 2015)

Table 11.2 Recorded hazardous flood events in Alexandria

\begin{tabular}{l|l|l|l|l}
\hline Date & $\begin{array}{l}\text { Rainfall } \\
\text { rate }\end{array}$ & $\begin{array}{l}\text { Rainfall } \\
\text { duration }\end{array}$ & Economic loss & Human loss \\
\hline $\begin{array}{l}31 \text { December } \\
1991\end{array}$ & $74 \mathrm{~mm}$ & N/A & N/A & 80 died \\
\hline 26 January 2004 & N/A & N/A & N/A & N/A \\
\hline $\begin{array}{l}12 \text { December } \\
2010\end{array}$ & N/A & N/A & $\begin{array}{l}15 \text { died } 11 \\
\text { injured }\end{array}$ \\
\hline $\begin{array}{l}14 \text { November } \\
2011\end{array}$ & N/A & N/A & N/A & \\
\hline $\begin{array}{l}29 \text { September } \\
2015\end{array}$ & $5 \mathrm{~mm}$ & $2 \mathrm{~h}$ & N/A & \\
\hline $\begin{array}{l}25 \text { October } 2015 \\
4 \text { November }\end{array}$ & $53 \mathrm{~mm}$ & $18 \mathrm{~h}$ & $\begin{array}{l}9.7 \text { million } \\
\text { dollars }\end{array}$ & $\begin{array}{l}13 \text { died } 16 \\
\text { injured }\end{array}$ \\
\hline
\end{tabular}

Source Data source: Elboshy et al. 2019

\subsubsection{Flood Risk Management (FRM)}

The FRM cycle consists of five main steps as follows: risk assessment, risk treatment (strategy), strategy implementation, strategy monitoring and evaluation, and risk goals and policy development and adjustments. In addition to these, risk communication participation is conducted in all steps, as shown in Fig. 11.7. Among these 5 steps, there are two main steps facing many challenges: flood risk assessment (FRA) and risk treatment (strategy).

FRAs are expected to enhance the effectiveness of disaster management, reduce the destructive socioeconomic impacts of floods and direct urban growth to safe areas (Cools et al. 2012). Therefore, FRAs are essential for identifying flood risk-prone areas in arid urban environments to mitigate flood risks and support-related decision making (Amundrud and Aven 2015; Psomiadis et al. 2016). An FRA defines the risk associated with floods for any city as a creation of both the city's exposure to the flood hazard and the vulnerability of society to the hazard. FRAs propose that the three main factors participating in a region's flood risk are hazard, exposure, and vulnerability (Center Asian Disaster Preparedness 


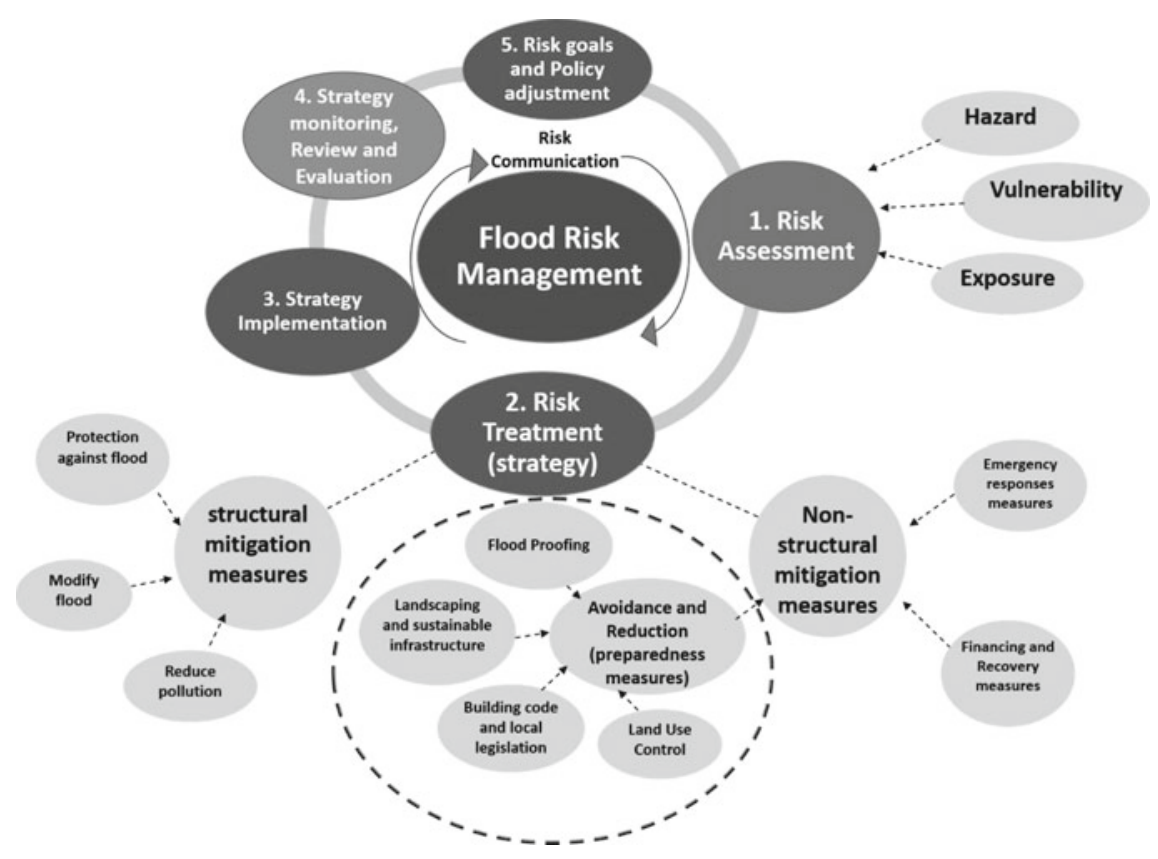

Fig. 11.7 Unified urban flood management (The Authors)

2005; Zhang et al. 2003). However, one of the main problems facing FRA is the inadequate level of vulnerability analysis and mapping, especially in arid regions (de Brito et al. 2017). Although there are many studies in this regard, most of the previous studies have focused on only FRA at regional scales. There is a notable limitation in FRA studies at the local scale.

Regarding risk treatment, which mostly concerns reducing current and future flood damage and the costs inherent in doing so, actions need to be taken. The main challenge in this step is that most governments depend mainly on structural flood mitigation measures. However, in some applications, it was found that nonstructural measures can facilitate the implementation of structural measures and ensure the achievement of structural objectives. Additionally, despite several decades of experience in urban planning tools and stormwater management strategy implementation for FRR in many developed countries, the application of such approaches in arid and semiarid regions has not yet received adequate attention. 


\subsection{Mitigation Measures for Flood Risk Reduction}

It is well known that FRR measures can be divided into structural and nonstructural measures. Structural measures are generally major public projects that require formal approval from one or more government units, moderate-to-major planning and design efforts, and moderate-to-large capital investments, operation, and maintenance commitments. Examples of structural measures used primarily to control the quantity of urban surface water are the construction of detention/ retention facilities, building banks or dams, upstream storage and diversion works, channel modifications or enclosures, dikes and floodwalls, bridges, channel improvement, and culvert alteration or replacement. Structural measures used mainly for controlling the quality of urban surface water are sedimentation basins, artificial or restored wetlands, and infiltration systems (Faisal et al. 1999). On the other hand, nonstructural measures usually include little or no construction and can often be implemented quickly by individuals, business, or other private entities. Typically, nonstructural measures require small-to-moderate capital investments. Nonstructural measures can be subdivided into land use regulation, institutional control, elevation of buildings, land acquisition and relocation, flood proofing, flood prediction and warning systems and emergency action plans, and flood insurance programs (Andjelkovic 2001; Faisal et al. 1999). Nonstructural measures aim to keep people safe from flooding by improving urban development planning and management. Structural measures are typically protective measures, while nonstructural measures are reduction measures. Experiences show that FRR must avoid single sectorial solutions. A comprehensive integrated strategy combining both structural and nonstructural mitigation measures should be linked to existing urban planning and management policies.

\subsubsection{Shortcomings of Structural and Nonstructural Mitigation Measures}

Structural measures can directly decrease the magnitude of flooding. However, there are many shortcomings of structural measures, as follows:

- Structural measures can be overtopped by events outside their design capacity.

- Many structural measures also transfer flood risk from one location to another.

- The redirection of water flows also frequently has environmental impacts. In some circumstances, this is acceptable and appropriate, while in others, it may not be. In all cases, a residual flood risk remains.

- Structural solutions can also have a high upfront cost, can sometimes induce complacency by their presence, and can result in increased impacts if they fail or are overtopped, as was tragically illustrated in the tsunami in Japan in 2011. 
Nonstructural measures do not usually require large investments upfront, but they often rely on a good understanding of flood hazards and adequate forecasting systems. However, there are many shortcomings of nonstructural measures, as follows:

- Many nonstructural measures lie in the need to engage the involvement and agreement of stakeholders and their institutions.

- Most nonstructural measures are designed to minimize but not prevent damage; therefore, most people would instinctively prefer a structural measure.

\subsubsection{Nonstructural Mitigation Measures}

The nonstructural measures shown in Fig. 11.8 and Table 11.3 can be categorized by their purposes into three main categories, as follows:

- Emergency planning and management including warning, evacuation, preparedness, and flood insurance.

- Flood avoidance and reduction via (1) land use planning such as (a) land use plans, (b) park and forestation plans, (c) land acquisition, and (d) relocation plans; (2) architectural planning measures such as (a) elevating buildings, (b) dry and wet flood proofing techniques, (c) facility maintenance and repair, (d) structural retrofitting or reinforcement, (e) building greening and (f) placement of pavements with water permeability.

- Speeding up recovery to increase resilience by enhancing building design and construction-"building back better".

\subsubsection{Urban Planning and Landscape Tools for Flood Risk Reduction}

Urban planning tools have recently played a central role in FRR scientific research. These tools can radically reduce the impact of extreme rainfall on public safety. In this part of the book, we will present some interventions that mainly lie under flood avoidance and reduction categories, such as (A) land use control, (B) building codes, (C) flood proofing and building elevation, and (D) sustainable infrastructure for stormwater management. 


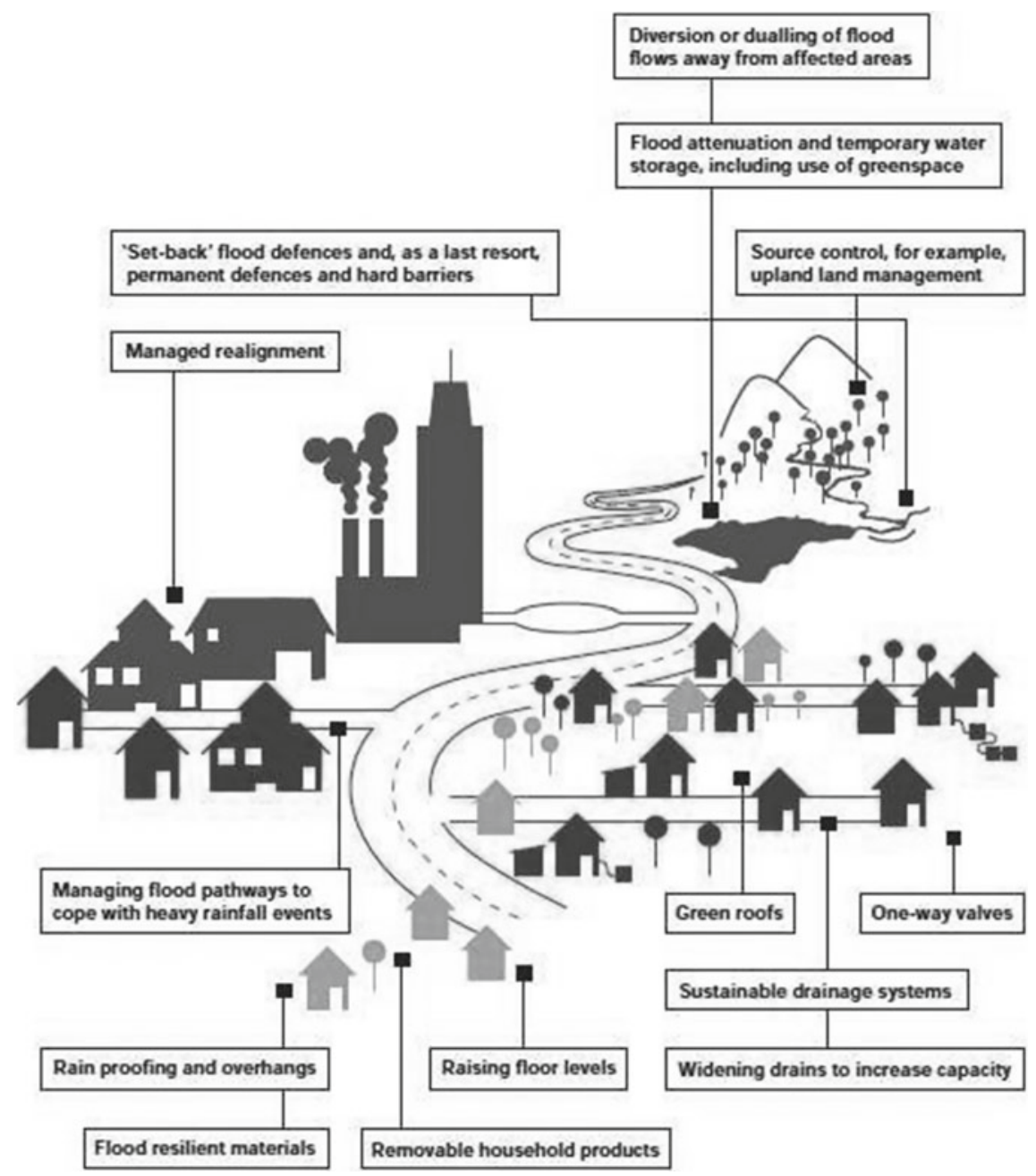

Fig. 11.8 Multiscale nonstructural mitigation measures (Modifed from: Shaw et al. 2007)

\subsubsection{Land Use Control and Flood Zoning}

One of the most operative methods of decreasing FR damage is to control development on a floodplain through land use planning, which requires the involvement of all levels of stakeholders (Şen 2018). According to the UN International Strategy for Disaster Reduction (ISDR) (2004) insufficient or nonexistent land use planning increases the vulnerability of communities exposed to natural hazards. Urban land tends to be the most vulnerable land to catastrophes wrought by floods, yet there are inadequate measures in place to reduce the impacts of floods on local populations. Although spatial planning is responsible for decisions regarding the long-term 
Table 11.3 Categories of nonstructural mitigation measures for FRR

\begin{tabular}{|c|c|c|c|c|}
\hline \multirow{13}{*}{$\begin{array}{l}\text { Category } \\
\text { Flood } \\
\text { avoidance } \\
\text { and } \\
\text { reduction }\end{array}$} & \multicolumn{3}{|c|}{ Subcategory } & Contents and characters \\
\hline & \multirow[t]{3}{*}{$\begin{array}{l}\text { Land use } \\
\text { plans }\end{array}$} & \multicolumn{2}{|l|}{ District plan } & $\begin{array}{l}\text { - Development control in } \\
\text { high-flood-risk areas }\end{array}$ \\
\hline & & \multicolumn{2}{|c|}{ Land use control } & $\begin{array}{l}\text { - Control the area outside } \\
\text { of the administrative } \\
\text { authority boundary } \\
\text { - Guide layouts of streets, } \\
\text { infrastructures, lot sizes } \\
\text { and shapes, and drainage } \\
\text { installations }\end{array}$ \\
\hline & & \multicolumn{2}{|c|}{ Water circulation plan } & $\begin{array}{l}\text { - Plan urban rain } \\
\text { circulation system }\end{array}$ \\
\hline & \multirow[t]{2}{*}{$\begin{array}{l}\text { Park and } \\
\text { forestation } \\
\text { plans }\end{array}$} & \multicolumn{2}{|c|}{$\begin{array}{l}\text { Open and green areas } \\
\text { development }\end{array}$} & $\begin{array}{l}\text { - Apply eco-friendly } \\
\text { standards and design } \\
\text { techniques for natural } \\
\text { drainage }\end{array}$ \\
\hline & & \multicolumn{2}{|c|}{ Waterfront park development } & $\begin{array}{l}\text { - Develop waterfront } \\
\text { parks and restrict } \\
\text { residential or commercial } \\
\text { developments }\end{array}$ \\
\hline & \multirow{5}{*}{$\begin{array}{l}\text { Land } \\
\text { acquisition } \\
\text { and } \\
\text { relocation } \\
\text { plans }\end{array}$} & \multirow{2}{*}{$\begin{array}{l}\text { Land } \\
\text { acquisition } \\
\text { and } \\
\text { development }\end{array}$} & $\begin{array}{l}\text { Public } \\
\text { development }\end{array}$ & $\begin{array}{l}\text { - Central and local } \\
\text { governments acquire land } \\
\text { and plan development }\end{array}$ \\
\hline & & & \begin{tabular}{|l|} 
Public/ \\
private \\
development \\
Sale of \\
development \\
rights
\end{tabular} & \\
\hline & & \multirow{3}{*}{$\begin{array}{l}\text { Land } \\
\text { rehabilitation } \\
\text { and } \\
\text { relocation }\end{array}$} & $\begin{array}{l}\text { Successive } \\
\text { residence }\end{array}$ & $\begin{array}{l}\text { - Rehabilitate the flooded } \\
\text { districts to maintain } \\
\text { existing buildings }\end{array}$ \\
\hline & & & $\begin{array}{l}\text { Individual } \\
\text { relocation }\end{array}$ & $\begin{array}{l}\text { - Partial relocation after } \\
\text { the rehabilitation of } \\
\text { high-flood-risk districts }\end{array}$ \\
\hline & & & $\begin{array}{l}\text { Complete } \\
\text { relocation }\end{array}$ & $\begin{array}{l}\text { - Land acquisition of } \\
\text { high-flood risk areas to } \\
\text { complete relocation }\end{array}$ \\
\hline & \multicolumn{3}{|c|}{ Building code } & $\begin{array}{l}\text { - Develop manuals or } \\
\text { guidelines for flood } \\
\text { prevention standards for } \\
\text { each district or building }\end{array}$ \\
\hline & \multicolumn{3}{|c|}{ Elevating buildings } & $\begin{array}{l}\text { - Elevate the ground } \\
\text { floors above the } \\
\text { inundation line } \\
\text { - Install pilots or piers and } \\
\text { elevate the inner floors of } \\
\text { buildings by filling land. }\end{array}$ \\
\hline
\end{tabular}


Table 11.3 (continued)

\begin{tabular}{|c|c|c|}
\hline Category & Subcategory & Contents and characters \\
\hline & Dry and wet flood proofing techniques & $\begin{array}{l}\text { Dry flood proofing } \\
\text { - sealing the exterior } \\
\text { walls to prevent the entry } \\
\text { of floodwater } \\
\text { - sealing all openings } \\
\text { below the flood line } \\
\text { - For wet flood proofing, } \\
\text { allow the entry of } \\
\text { floodwater but keep the } \\
\text { same level of pressures } \\
\text { between the inside and } \\
\text { outside building to } \\
\text { mitigate damages on the } \\
\text { structure including the } \\
\text { foundation }\end{array}$ \\
\hline & $\begin{array}{l}\text { Facility maintenance, repair, and structural } \\
\text { retrofitting or reinforcement }\end{array}$ & $\begin{array}{l}\text { - Repair, maintain or } \\
\text { protect facilities from } \\
\text { floods } \\
\text { - Structural retrofitting to } \\
\text { prevent buildings being } \\
\text { washed away } \\
\text { - Build waterproof walls } \\
\text { or fences }\end{array}$ \\
\hline & $\begin{array}{l}\text { Sustainable infrastructure for stormwater } \\
\text { management, building greening, and pavements }\end{array}$ & $\begin{array}{l}\text { - Install roof gardens, } \\
\text { vertical garden walls, etc., } \\
\text { directly or indirectly to } \\
\text { mitigate flood damage } \\
\text { - Pave façade, part, or } \\
\text { whole of buildings with } \\
\text { water-permeable } \\
\text { materials }\end{array}$ \\
\hline \multirow[t]{2}{*}{$\begin{array}{l}\text { Speeding up } \\
\text { recovery }\end{array}$} & Flood prevention standards & $\begin{array}{l}\text { - Increase resistance by } \\
\text { enhancing building } \\
\text { design and construction } \\
\text { after disasters occur }\end{array}$ \\
\hline & Restoration policy and risk finance & \\
\hline \multirow{4}{*}{$\begin{array}{l}\text { Emergency } \\
\text { planning } \\
\text { and } \\
\text { management }\end{array}$} & Statutes and ordinances & \\
\hline & Public information and education & $\begin{array}{l}\text { - Emergency action plans } \\
\text { - Disaster prevention } \\
\text { education }\end{array}$ \\
\hline & $\begin{array}{l}\text { Flood prediction, warning, and evacuation } \\
\text { systems }\end{array}$ & $\begin{array}{l}\text { - Including evacuation } \\
\text { facilities and flood maps }\end{array}$ \\
\hline & Flood insurance & $\begin{array}{l}\text { - Evaluation system of } \\
\text { flood risk, flood mapping, } \\
\text { and coordination with } \\
\text { urban architectural plans }\end{array}$ \\
\hline
\end{tabular}

Source Data source: Kang et al. 2009 
utilization of land and has not been directly responsible for disaster risk reduction, it has a fundamental role in disaster risk reduction. Four likely roles of spatial planning in FRR, as identified by Fleischhauer (2008), are as follows:

- Eliminate future urban expansion in flood-prone zones by determining the locations in which building is or is not allowed according to the flood risk degree of each location, especially concerning the history of flood incidences, as shown in Fig. 11.9.

- Classify different land use settings for flood-prone areas by identifying sensitive or important societal or environmental features since each disaster has its own acceptable risk to different land use classes.

- Regulate land use or zoning plans by identifying appropriate area(s)/location (s) for specific land uses with legally necessary statuses. In areas vulnerable to floods, the regulation of building density is essential to decrease the impact of building collapse. Simply, land regulation determines where urban development should go (Pyke and Andelman 2007).

- Achieve flood hazard alteration by promoting a soft engineering method to decrease FR.

Spatial planning processes need to integrate several factors and datasets. Topographical and natural feature maps are considered base maps that enable a spatial understanding of all other features, such as buildings, infrastructure, open spaces, green belts, nature reserves and watercourses. The division of maps into layers helps policy makers interpret community needs and address potential hazards and risks. Using geographical information systems (GISs) has become essential for

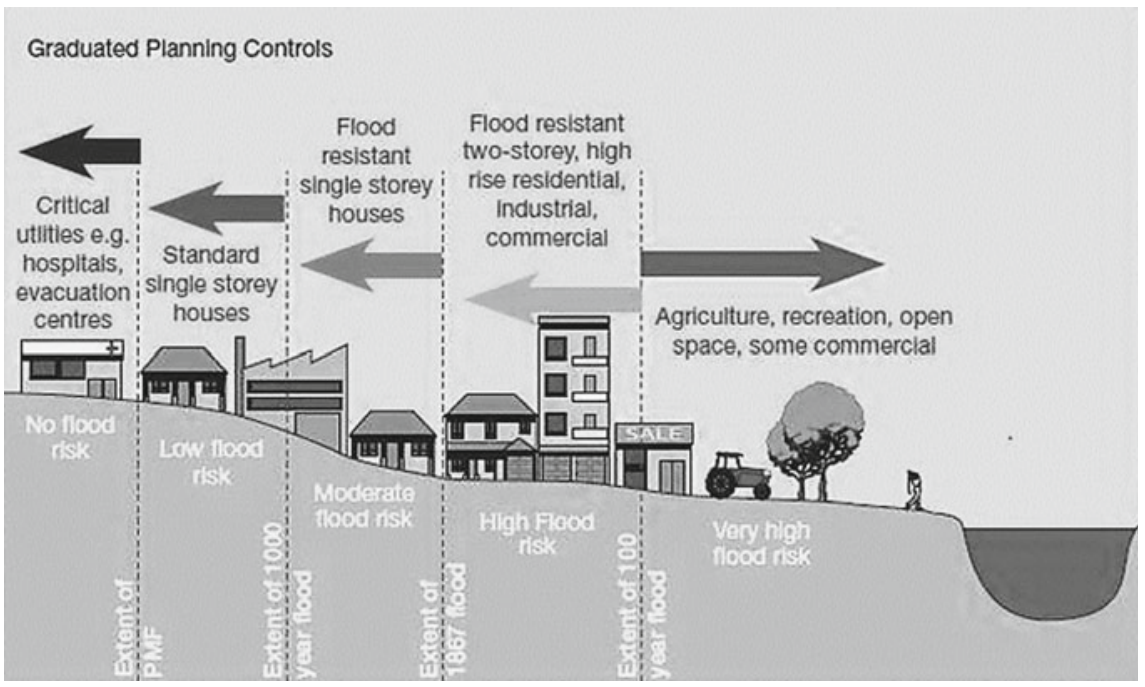

Fig. 11.9 Land use planning controls according to flood risk degree (Modifed from: How can flooding be stopped? 2020) 
different governmental entities to capture relevant urban data spatially and address growing issues.

Environmental economists have emphasized the importance of spatial measures as part of a more "risk-based" approach in flood management, wherein spatial measures can be integrated with structural flood measures to reduce flood risk. However, the cost and expected benefits are the main determinants of differentiation between different structural and spatial measures (Liao 2012).

\subsubsection{Flood Proofing and Elevating Buildings}

The damage to infrastructure elements and houses in flood events can be caused by direct water forces, erosion, or a combination of both (Santato et al. 2013). There are many techniques for the flood proofing of properties. (1) Elevation: lifting the buildings or infrastructure elements higher than expected flood level, which prevents them from intersecting with the path of water movement. Also, building elevated walkways improves accessibility to important buildings such as flood shelters. (2) Flood walls: built to keep floodwaters from reaching buildings. (3) Dry flood proofing: making the walls of buildings and the openings resistance to water. (4) Wet flood proofing: minimizing the damage that occurs when water enters the building, as shown in Fig. 11.10.
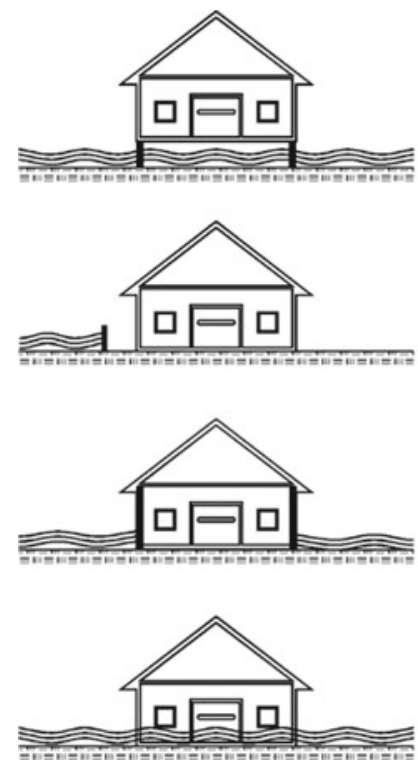

Elevation:

Raising a building so that flood waters will go under it

Fig. 11.10 Techniques to fight floods in cities. (Modifed from: UNESCO. Fighting floods in cities; Project training material for disaster reduction; Report, Delft, Holland 1995)

Dry floodproofing:

Making the walls of the building and the openings watertight

\section{Wet floodproofing: \\ Altering a building to minimize damage when flood waters enter}

Floodwalls:

Building a wall to keep flood water from reaching a building 


\subsubsection{Creation of Regulations and Enforcement Procedures}

Integrating land use planning with flood risk management by identifying flood zones and determining the developmental frameworks achieves appropriate land use planning and patterns of development. However, the effectiveness of these plans requires appropriate regulations to control or restrict development. Such regulations will need to interact with existing land use control, planning and building control legislation and will be naturally limited by the strength of current land use planning procedures. For example, in Germany, flood legislation was built upon an already stringent planning control system with good compliance and is expected to have a long-term impact on flood risk. The regulations usually cover the following aspects (Andjelkovic 2001):

- Selecting the appropriate uses for new development areas and associated permitted zones

- Flood risk assessment requirements for any new developments

- Design and building standards for flood zones such as materials, access points, and minimum floor level

- Mandatory drainage and surface water management plans

- Mandatory retrofitting of flood protection measures

\subsubsection{Sustainable Infrastructure for Stormwater Management}

Sustainable drainage is a strategy usually applied to urban areas that are prone to different flooding types due to heavy rain. In urban areas, built-up areas and paved roads are impermeable to water, and rain is channeled straight into drainage networks that can quickly become submerged. The main concept of sustainable infrastructure is to utilize landscape elements and make the water from roofs and roads drain underground rather than occupy the water system (Jia et al. 2015), as shown in Fig. 11.11.

The complexity of urban stormwater management has been increasing over recent decades, and many concepts, tools and techniques have been utilized to reduce flood risk. These concepts, tools and techniques have been used by experts of different disciplines in different regions of the world. Additionally, different disciplines are integrated into this issue, such as the urban drainage discipline, architecture, landscape architecture, urban design and planning, sociology, ecology, and economics. This section will discuss some of the urban planning tools, strategies and techniques for FRR in urban areas as follows: best management practices (BMPs) and low impact development (LID) between 1949 and 1990 in the USA; water-sensitive urban design (WSUD) in the 1990s in Australia; sustainable urban drainage systems (SUDS) in the 2000s in the UK; green infrastructure (GI) and green-gray infrastructure; integrated urban water management (IUWM) and sponge cities in 2014-2015 in China. The main common goals for all these tools, strategies and techniques are as follows: 


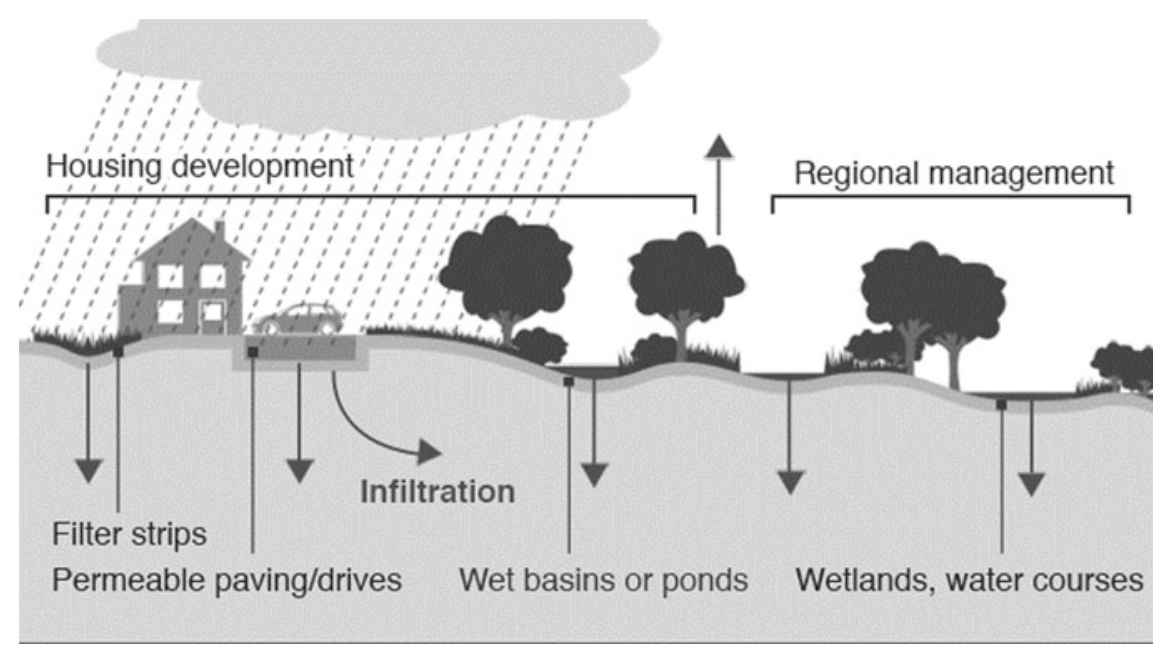

Fig. 11.11 Main concept of sustainable infrastructure for stormwater management (Modifed from: How can flooding be stopped? 2020)

- Reduce runoff volumes and flow rates from impermeable surfaces

- Control the impact of urbanization on flooding

- Provide opportunities for using runoff water at the point of fall

- Improve water quality and reduce pollution from runoff water

- Protect natural flow system in watercourses

- Provide an attractive habitat for wildlife in urban watercourses

- Provide opportunities for evapotranspiration from vegetation and surface water

- Support natural groundwater/aquifer recharge.

\section{Best Management Practices (BMPs) and Low Impact Development (LID)}

By the early 1990s, the term BMP had been adopted in almost every jurisdiction's stormwater design manual, and consequently, BMPs were implemented across North America. LID is considered as a sub-strategy of BMPs. The main goal of LID was to achieve a natural hydrology system by integrating control measures. Natural hydrology refers to the predevelopment runoff, infiltration, and evapotranspiration volumes that achieve the site's balance through a functionally equivalent landscape. The LID layout applies a cascading flow system to minimize the direct connectivity between adjacent impervious areas. LID mainly concerns the spread of runoff flows produced from upper impermeable surfaces onto lower permeable areas, such as absorbent landscaping areas, for additional infiltration benefits and water quality enhancement. LID depends on small-scale stormwater treatment devices such as bioretention systems, green roofs, and swales located at or near the source of runoff (Fletcher et al. 2015). 
The LID-BMP implementation should be fully coordinated with the local construction plan and integrated, if possible, into the site landscaping scheme. The LID-BMP planning strategy includes the following: (1) preserving the original terrain, (2) limiting the ratio of impervious surface areas, (3) avoiding the direct connection of impervious areas, (4) selecting the most suitable BMP types according to local conditions in terms of both technical and social/economic factors, and (5) setting an appropriate goal for LID-BMP implementation (Fletcher et al. 2015).

\section{Water-Sensitive Urban Design (WSUD)}

The objectives of the WSUD strategy are to manage the water balance of an urban area, maintain and improve water quality, support water conservation, and maintain water-related environmental and recreational issues. The WSUD approach aims to minimize the hydrological impacts of urban development. Stormwater management as a main target of WSUD includes different objectives, such as providing flood control, flow management, water quality improvements and opportunities to harvest stormwater (Fletcher et al. 2015).

\section{Sustainable Urban Drainage System (SUDS)}

SUDS contains various techniques to drain rainfall water in a sustainable manner. The techniques used depend on replicating as closely as possible the natural, predevelopment drainage conditions of a site, consistent with the previously described principles behind LID. Typically, SUDS are designed as a sequence of practices and technologies that work together to form stormwater management (Fletcher et al. 2015).

\section{Integrated Urban Water Management (IUWM)}

The concept of integrated urban water management (IUWM) integrates the management of water supply systems, groundwater, wastewater networks, and stormwater drainage, considering the roles and cooperation between the different institutions involved in urban water management. The IUWM is based on considering all parts of the water cycle regardless of whether that water cycle is natural or constructed and surface or subsurface, recognizing these factors as an integrated system, considering all requirements for water, both anthropogenic and ecological, and considering the local context. Additionally, the IUWM concept accounts for environmental, social, cultural and economic perspectives and needs and strives for sustainability by achieving a balance among these perspectives (Jia et al. 2012). 


\subsubsection{Sustainable Infrastructure Tools for Stormwater Management}

To apply the different sustainable infrastructure strategies discussed in the previous section, different tools have been used and integrated to achieve the desired objective (Hamburg: Hamburg University of Technology (TUHH) n.d.). In the following section, these different tools are divided into three categories: recharge (infiltration) tools, detention tools, and retention tools, as shown in Fig. 11.12.

Recharge Infiltration Tools

Infiltration tools involve stormwater runoff soaking into the ground to reduce the volume of rainfall water runoff on the surface.

Fig. 11.12 Sustainable infrastructure for stormwater management tools (Modifed from: Hamburg: Hamburg University of Technology (TUHH) n.d.)

\section{a) Recharge basin}

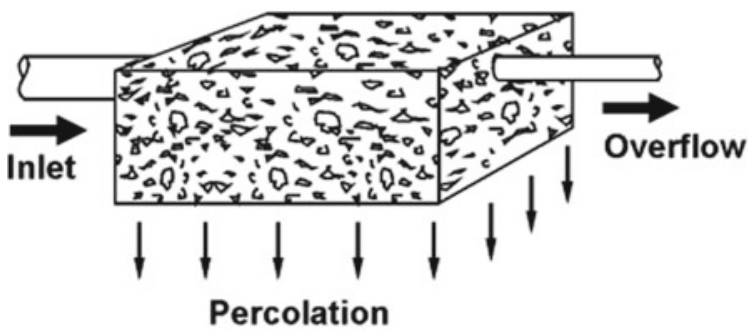

b) Detention basin

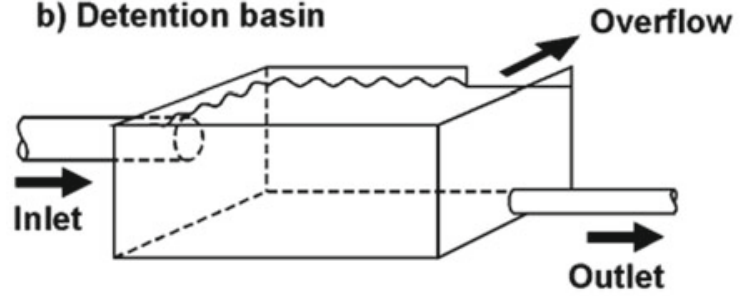

c) Retention basin

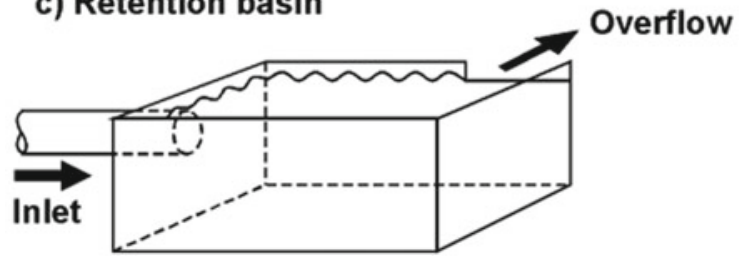




\section{A. Bioswales}

Bioswales are vegetated channels with permeable soils that infiltrate runoff water from upgradient impermeable areas (Blanco et al. 2011), as shown in Fig. 11.13.

\section{B. Stormwater Planters}

Stormwater planters have an essential role in the sustainability of urban areas by reducing stormwater runoff and water pollution. In addition, stormwater planters play an important role in creating a greener and healthier built environment by providing space for plants and trees near buildings and along streets (Rehan 2013).

Stormwater planters are similar to rain gardens: They are designed to capture runoff and filter out sediment and pollutants, as shown in Fig. 11.14.

\section{Permeable Pavements}

Permeable pavements refer to the use of a special technique to pave urban paths that permits stormwater runoff to infiltrate through the surface into the sublayers and/or underlying strata, as shown in Fig. 11.15.

Different alternatives can be used as permeable pavements, such as permeable concrete block pavers, brick pavers, stone chips, gravel, porous concrete, and porous asphalt. Additionally, grass can be used with or without reinforcement in areas with suitable climates and low traffic loading. Permeable paving is generally constructed on a coarse gravel subbase that creates temporary storage facilities and allows stormwater runoff to infiltrate into the underlying stratum, promoting the recharge of the groundwater table. Stored rainwater can be reused for several domestic purposes.

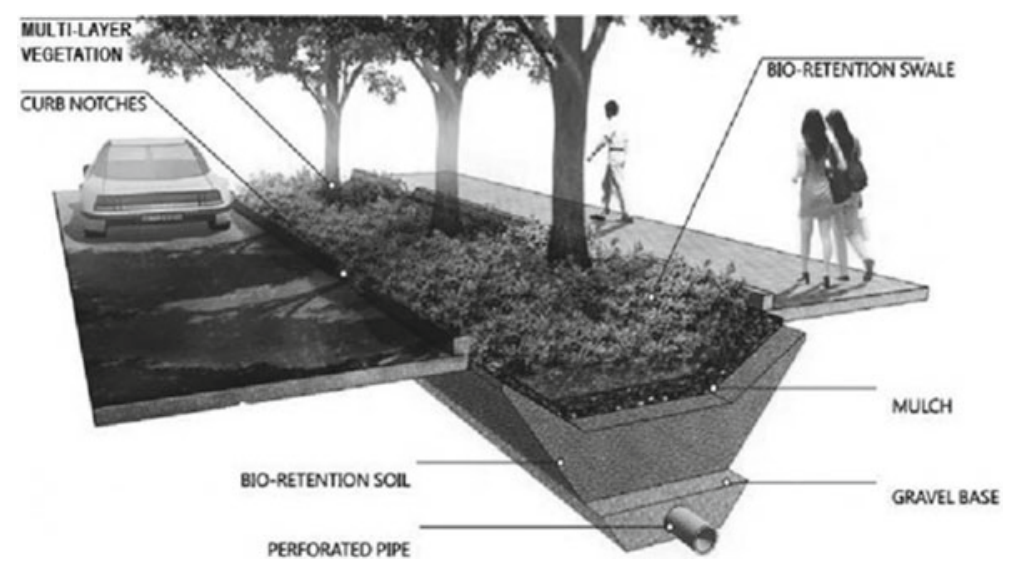

Fig. 11.13 Bioswales design (Modified from: Brankovic and Protic) 


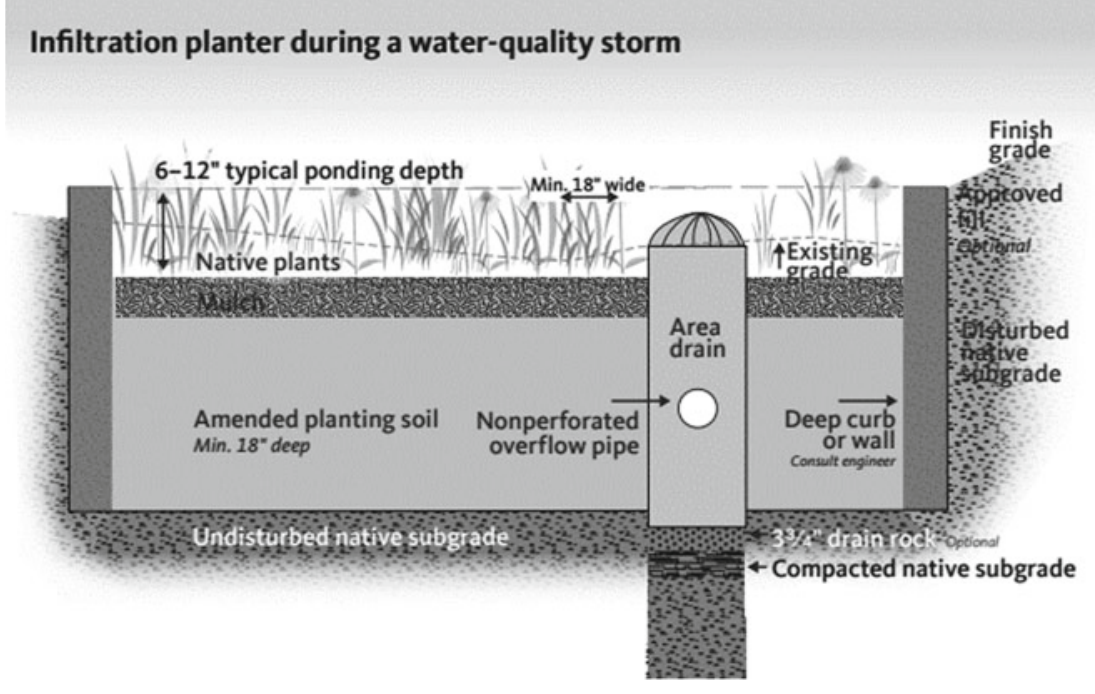

Fig. 11.14 Infiltration stormwater planter design (Modified from: Cahill et al. 2011)

Fig. 11.15 Permeable concrete block pavers with open joints and slotted ends filled with pea-sized gravel (Modified from: Armitage et al. 2013)

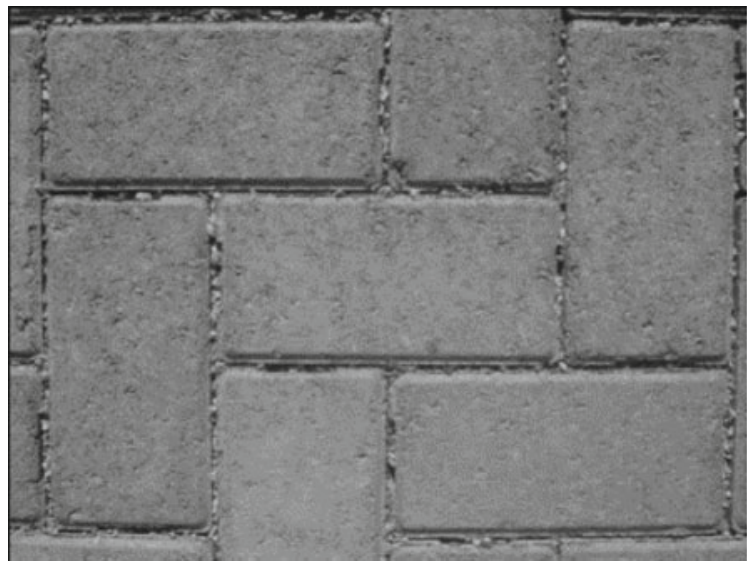

\section{Detention Tools}

Detention tools are used to slow down stormwater runoff before subsequent transfer downstream. The following section discusses different detention tools.

\section{A. Detention Ponds}

Detention ponds are large depressions that work as temporary storage for stormwater runoff and reduce flood peaks. Detention ponds are known as dry ponds and provide only flood control measures. The estimation of detention pond volume 
depends on comparing the runoff volumes before and after development in urban areas. The ponds are intended to drain stormwater within a given period to make their volumes available for the next storm event. As shown in the diagram below, outlet pipes are placed at the bottom elevation of detention ponds to allow the ponds to drain dry.

\section{B. Subsurface Storage}

The subsurface storage of stormwater involves underground structures that are used to temporarily detain and release stormwater. These structures can include vaults, stone storage, pipe storage, and plastic grid storage. Successful stormwater management plans will combine materials and designs that are specifically appropriate to each site, as shown in Fig. 11.16.

\section{Retention Tools}

Retention tools are used for the retention of rainfall water to protect receiving watercourses during floods if long-term storage and additional infiltration are not feasible on site. The following section discusses different retention tools.

\section{A. Retention Ponds (retention basins)}

Retention ponds are formed by excavating below the natural groundwater level and/or lining the bases of ponds to retain stormwater. In contrast to dry detention ponds, retention ponds hold permanent pools of water and are referred to as wet ponds. Usually, the main reason to construct retention ponds involves high

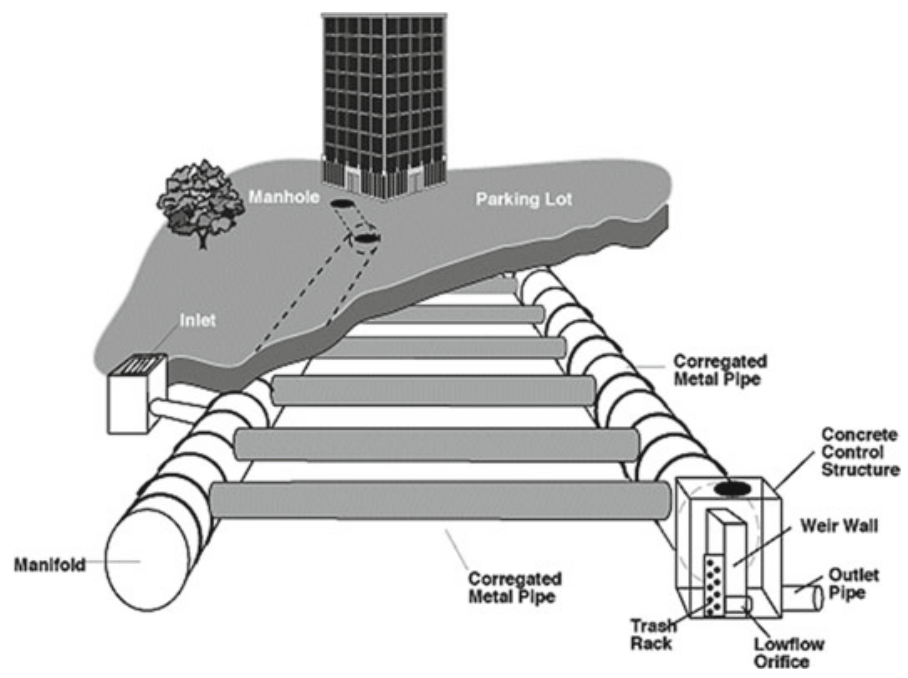

Fig. 11.16 Subsurface storage stormwater components (Modified from: Underground Storage) 
groundwater tables. The bottom of the ponds is excavated below the water table elevation to establish a permanent pool. The outlet of the pond is placed above the desired pool elevation. The volume of the permanent pool is estimated by a desired residence time to allow microbes and vegetation in the water to consume nutrients and to allow suspended pollutants to settle.

\section{B. Constructed Wetland}

Constructed wetland technology is considered to be a comprehensive approach integrating wastewater treatment, flood protection and stormwater management. Gray water is collected from households and subjected to a primary treatment system (usually a septic tank) and is then transported to the constructed wetland via an inlet to pass through the filter media, allowing the settlement of solids and trapping bacterial populations on the surface of the media and plant stems. Wastewater then reaches the outlet with higher quality and can be reused, as shown in Fig. 11.17.

\section{Green Roofs}

Green roofs are a technique involving covering rooftops with lightweight plants that enable rainfall infiltration and recover evapotranspiration. As shown in Fig. 11.18, green roofs basically consist of a vegetation layer, a substrate layer that is important to retain water and in which the vegetation is anchored and a drainage layer to drain the excess water. Grasses, perennial herbs and shrubs make up the main constituents of vegetation (Mentens et al. 2006).

Green roofs reduce stormwater through three processes: delaying the initial time of runoff by absorbing water in the green roof system; reducing the total runoff by retaining a portion of the rainfall water; and distributing the runoff over a long time period through a relatively slow release of the excess water that is temporarily stored in the pores of the substrate.

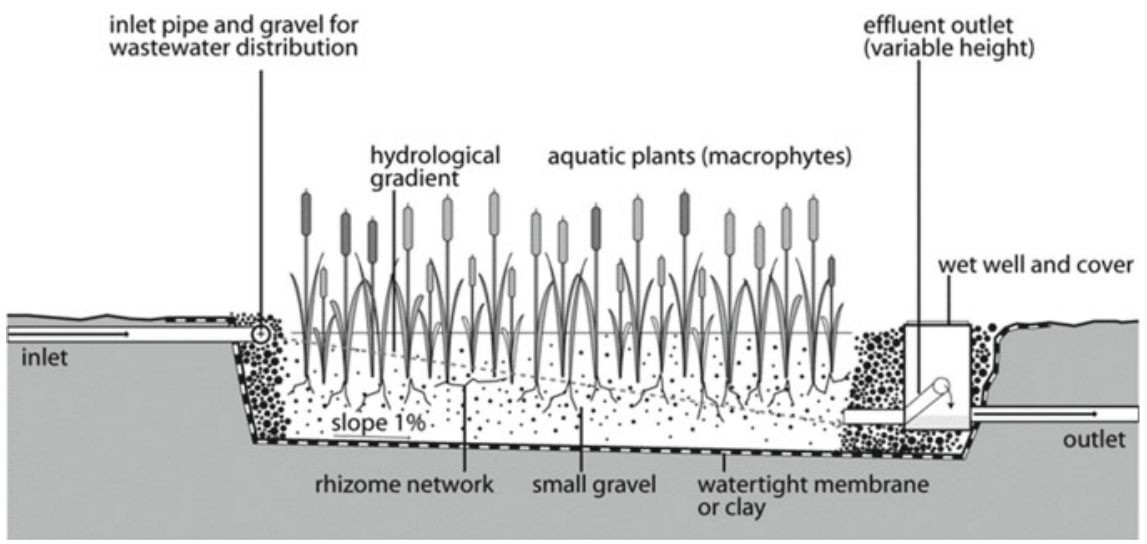

Fig. 11.17 Horizontal subsurface flow in a constructed wetland (Modified from: Tilley 2014) 


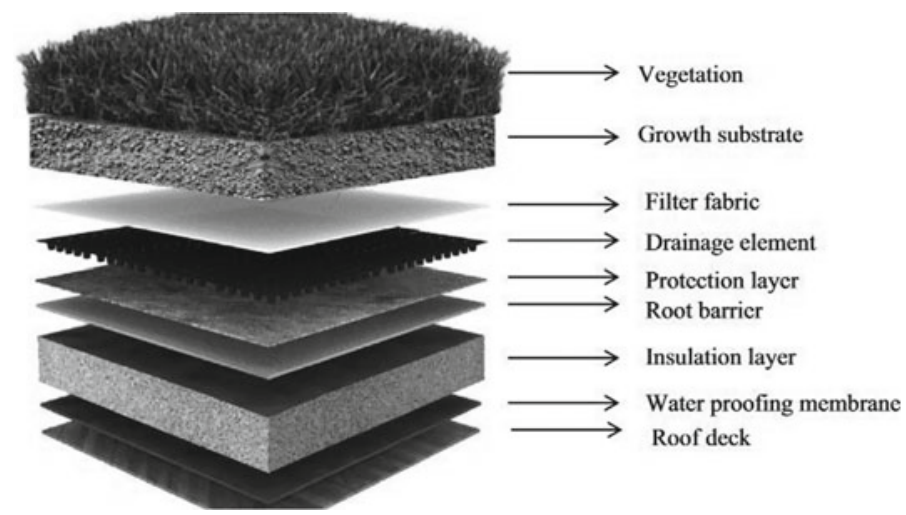

Fig. 11.18 Green roof structure (Modified from: InsulationCorp 2018)

\section{Rainwater Harvesting}

Rainwater harvesting involves the collection and use of rainfall water from any catchment area, such as roofs, to reduce site runoff and the need for runoff-control devices and to minimize the need for utility-provided water. Rainwater collection has been widely used in arid regions. Particularly in areas where populations are dispersed, rainwater collection constitutes a low-cost alternative to provide needed water. In moist climate zones, rainwater collection is an efficient supplemental water source, as shown in Fig. 11.19 (Annie Kane and The Fifth Estate 2015).

\subsection{Implementation of Specific Urban Water Management in Arid and Semiarid Regions}

The application of such approaches in arid and semiarid regions has not yet received adequate attention. Therefore, due to the limitations of existing case studies, this section will briefly present 3 case studies involving the implementation of urban water management strategies and techniques in the semiarid region of China and the USA in addition to Egypt.

\subsubsection{Sponge City-China}

The Sponge City Program (SCP) was embraced by the Chinese government in 2014. This program aims mainly to provide nature-based solutions for urban water-related issues. The main goals were to absorb and reuse $70 \%$ of stormwater in urban areas by improving and enhancing the infiltration rate and storing and 


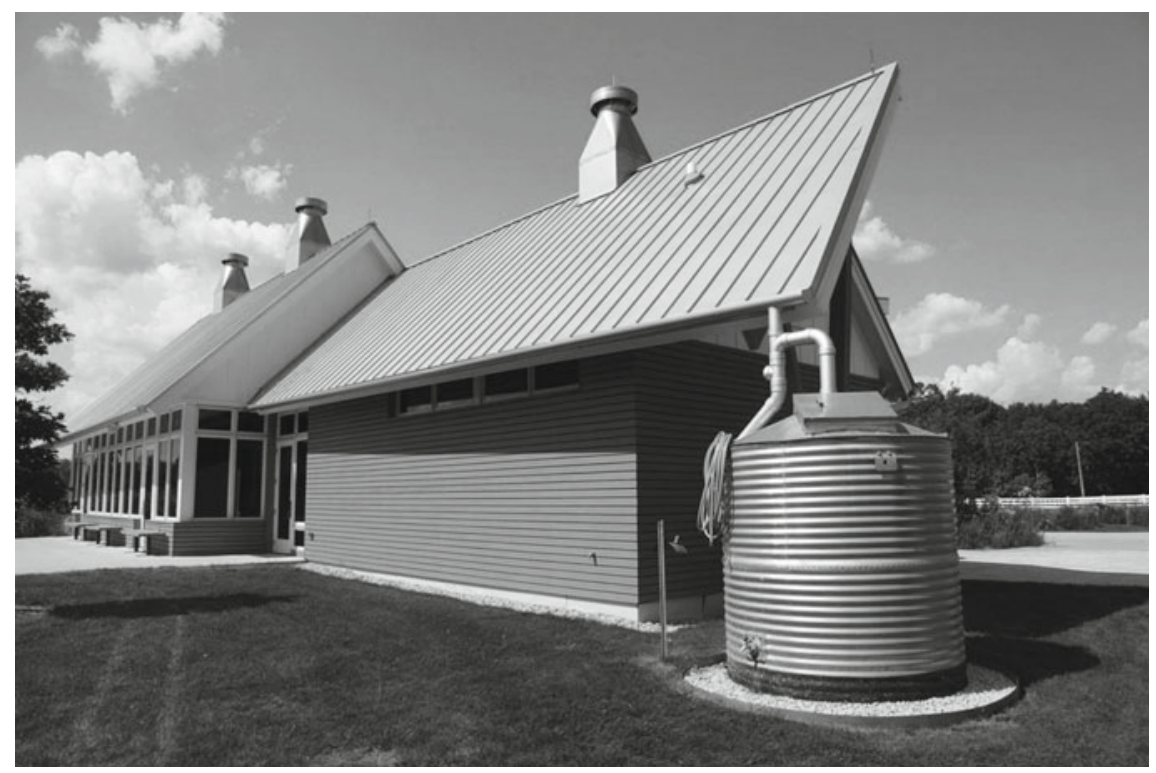

Fig. 11.19 Rainwater harvesting example (Modified from: Annie Kane and The Fifth Estate 2015)

purifying rainwater for reuse. The main techniques adopted in this program are the replacement of impervious infrastructure systems, green roofs, parks, and waterfront areas following a sustainable or greener approach, as shown in Figs. 11.20 and 11.21 (DSD). The harvested rainwater, after suitable treatment, can be used as far as possible as a water resource. Approximately 50-100 million US\$ for each pilot city has been invested in the SCP by the Chinese central government, which allows more cities to join the program (Nguyen et al. 2019).

\section{LID_USA}

By the early 1990s, LID was implemented across North America. The main aims of LID are slowing the flow of stormwater and reducing erosion and flood-related dangers. This aim can be achieved by spreading stormwater out, which reduces the flow speed. Thus, the stormwater is absorbed into the ground as recharge. Green roofs (Fig. 11.22), rain gardens, porous pavements, planter boxes (Fig. 11.23), bioswales, and detention/retention ponds (Fig. 11.24) have been adopted in Denver, $\mathrm{CO}$ and other cities by the United States Environmental Protection Agency (EPA). Rain gardens are placed near paved surfaces, such as parking lots, to catch runoff. Additionally, rainwater is stored in planter boxes and then channeled into rain gardens. Bioswales/bioretention cells are used to purify contaminants and pollutants from stormwater runoff (Agency 2017). 


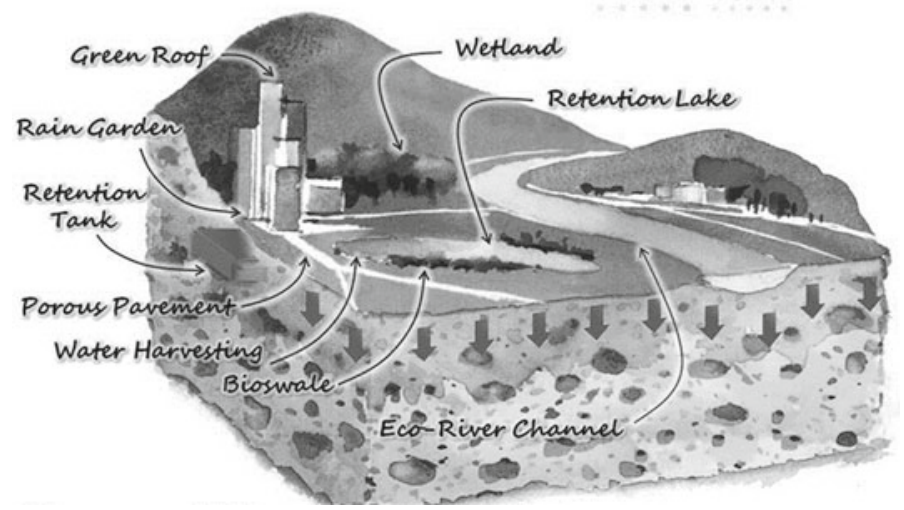

Fig. 11.20 Schematic diagram of the sponge city main concept (Modified from: DSD)

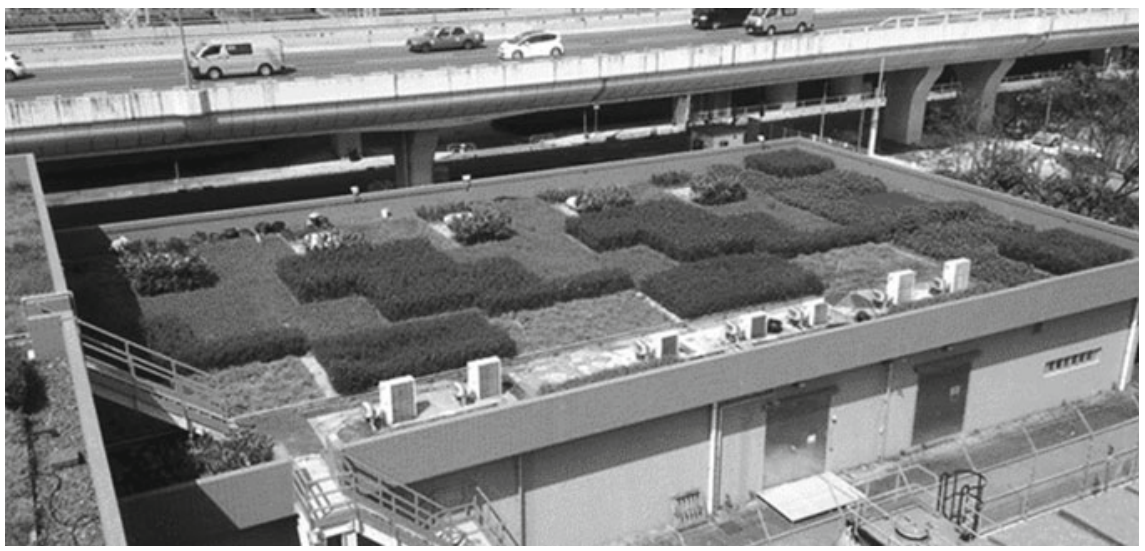

Fig. 11.21 Green roof at Shatin Sewage Treatment Works (Modified from: DSD)

Detention/retention ponds are used due to an increase in flash flood events in Denver. Detention and retention ponds provide locations for the collection and infiltration of rainwater into aquifers. The main difference between detention and retention ponds is that during scarce rainfall, detention ponds stay dry, while retention ponds include constant amounts of water, as shown in Fig. 11.24. (Agency 2017) 

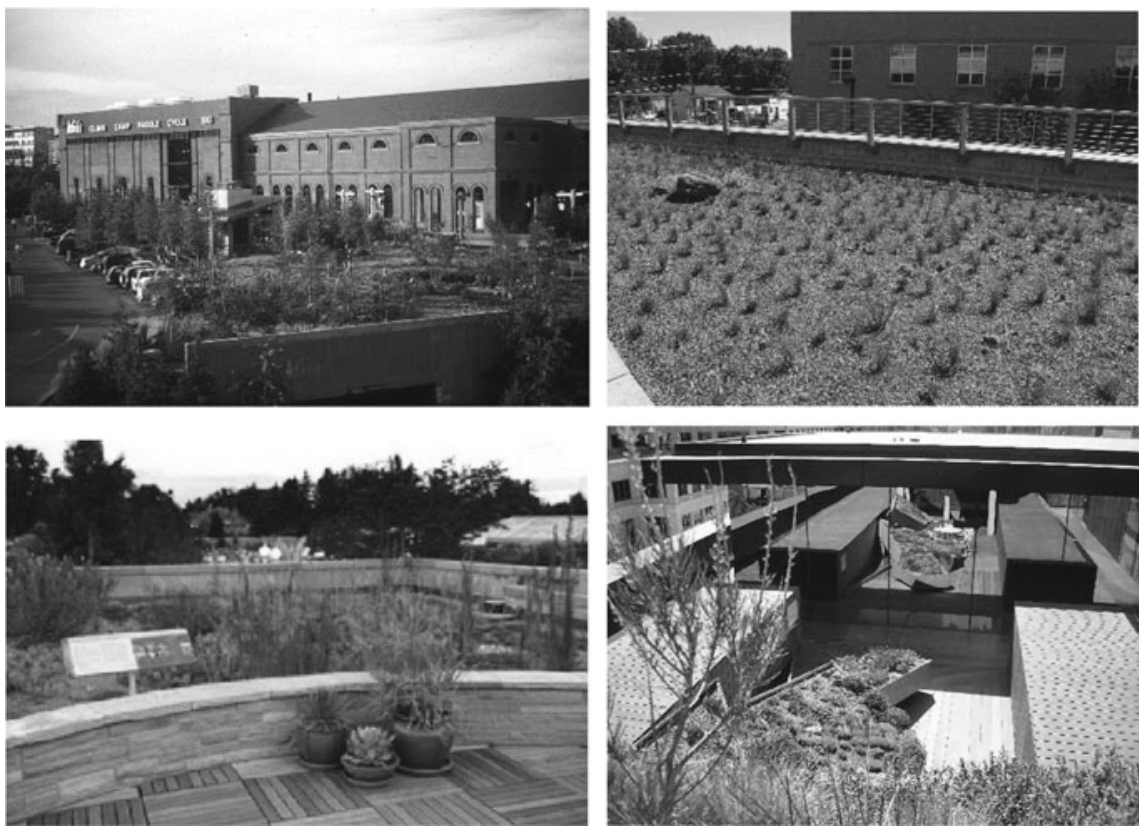

Fig. 11.22 Green roof technique in Denver, CO, USA, for stormwater management (Modified from: Agency 2017)
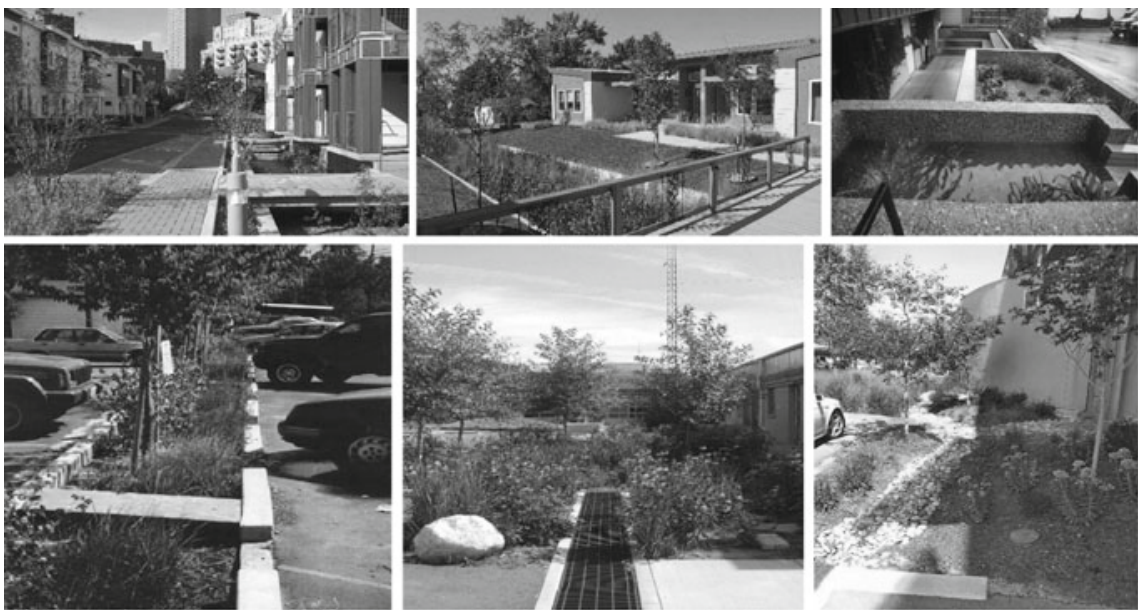

Fig. 11.23 Rain gardens, porous pavements, and planter box techniques in Denver, CO, USA, for stormwater management (Modified from: Agency 2017) 

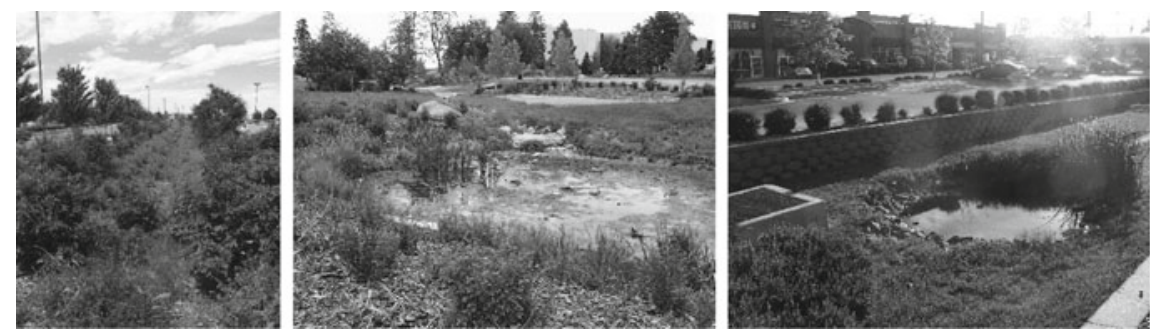

Fig. 11.24 Bioswale and detention/retention pond techniques in Denver, CO, USA, for stormwater management (Modified from: Agency 2017)
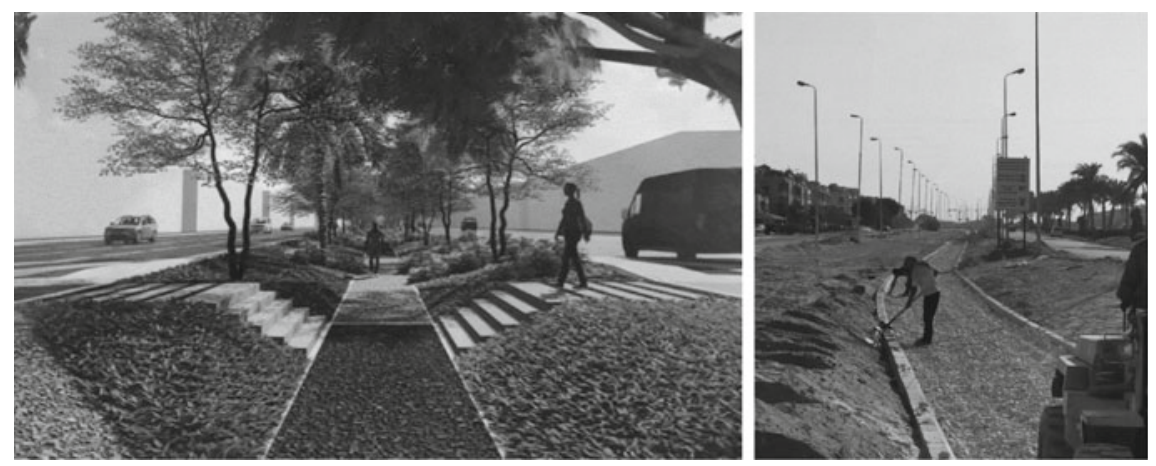

Fig. 11.25 Bioswales, storm planters, and infiltration tools in New Cairo city

\subsubsection{Recharge Infiltration-Egypt}

For the first time in Egypt, in 2020, officials began to pay attention to nonstructural mitigation measures for FRR in urban areas, especially new cities. Bioswales, storm planters, and infiltration tools were used in New Cairo city to decrease the volume of stormwater runoff on the surface since the city has recently suffered repeatedly from urban flooding, as shown in Fig. 11.25.

\subsection{Conclusion}

Solutions for flood management in urban areas are regularly complex because the urbanization process does not result from the optimal use of space or integrated planning. Structural mitigation measures are still common, especially in developing urban environments where flooding disasters and water-related issues must be addressed. Despite several decades of experience in the use of urban planning tools and stormwater management strategy implementation for FRR in many developed 
countries around the world, such as the USA, UK, Australia, China, and Netherlands, the application of such approaches in arid and semiarid regions has not yet received adequate attention yet.

The effectiveness of stormwater strategies is flow-path dependent. It is necessary to develop cascading flows to drain storm runoff from impervious surfaces upstream onto pervious areas downstream for more infiltration. When LID, SUDS, Sponge Cities and GI are implemented in arid and semiarid climates, native plants that can cope with drought and are low-maintenance must be chosen due to the dry climate and large temperature differences between summer and winter.

Many challenges are faced when implementing the urban planning approach in flood risk reduction. These challenges include political interventions, unsatisfactory resources, and state inaction to involve civil society in planning and environmental processes. Land use planning and regulation are fundamental measures for future FRR to mitigate the devastating impacts of flooding, particularly in rapidly urbanizing areas.

Accordingly, the integration of a disaster risk reduction strategy combining both structural and nonstructural mitigation measures into spatial planning is vital. This integrated strategy could be much more effective than using one type of measure alone. Therefore, it is essential to simulate the future impacts of flood disasters. Spatial plans should be assessed alongside integrated risk maps to understand the possible consequences of disasters on land use allocation. Planning exercises must be conducted with the contribution of all relevant agencies to develop a framework for holistic flood management within the country. The new city plans must include such urban and landscape tools for FRR in the current and future situations while considering the uniqueness of the local context.

\section{References}

Abdel-Fattah M, Kantoush S, Sumi T (2015) Integrated management of flash flood in wadi system of Egypt: disaster prevention and water harvesting

Abdrabo KI, Kantoush SA, Saber M, Sumi T, Habiba OM, Elleithy D, Elboshy B (2020) Integrated methodology for urban flood risk mapping at the microscale in ungauged regions: a case study of Hurghada, Egypt. Remote Sens 12(21):3548

Agency USEP (2017) Low-impact development and green infrastructure in the semi-arid west. Retrieved from https://www.epa.gov/green-infrastructure/green-infrastructure-semi-arid-west

Amundrud Ø, Aven T (2015) On how to understand and acknowledge risk. Reliab Eng Syst Saf 142:42-47. https://doi.org/10.1016/j.ress.2015.04.021

Andjelkovic I (2001) Non-structural measures in urban flood management; IHP-V technical documents in hydrology No. 50. UNESCO, Paris, France

Annie Kane and The Fifth Estate. 2015. Rainwater harvesting could save australia billions. Retrieved from (https://www.eco-business.com/news/rainwater-harvesting-could-saveaustralia-billions/?fbclid=IwAR3vRFZTGWqaaiv-LOqsxb0aAgZhGkAKGgtiwGCixhnWzc8wm UHt9U7SAS8)

Armitage N, Vice M, Fisher-Jeffes L, Winter K, Spiegel A, Dunstan J (2013) The South African guidelines for sustainable drainage systems. Report TT558/13. Pretoria: water research commission 
Ashraf Abdalhameed (2015) The floods killing 6 persons in Alexandria. Alarabia news. Retrieved from https://www.alarabiya.net/arab-and-orld/egypt/2015/10/25/

Bertilsson L, Wiklund K, de Moura Tebaldi I, Rezende OM, Veról AP, Miguez MG (2019) Urban flood resilience - a multi-criteria index to integrate flood resilience into urban planning. J Hydrol 573:970-982

Blanco H, McCarney P, Parnell S, Schmidt M, Seto K (2011) The role of urban land in climate change. Climate change and cities: first assessment report of the urban climate change research network. Cambridge University Press, Cambridge, UK

Cahill MR, Godwin D, Sowles M (2011) Stormwater planters: Oregon sea grant

Cardona O-D, van Aalst MK, Birkmann J, Fordham M, McGregor G, Mechler R (2012) Determinants of risk: exposure and vulnerability

Center Asian Disaster Preparedness (2005) Integrated flood risk management in Asia: A Primer. Retrieved from

Cools J, Vanderkimpen P, El Afandi G, Abdelkhalek A, Fockedey S, El Sammany M, Huygens M (2012) An early warning system for flash floods in hyper-arid Egypt. Nat Hazards Earth Syst Sci 12(2):443-457. https://doi.org/10.5194/nhess-12-443-2012

de Brito MM, Evers M, Höllermann B (2017) Prioritization of flood vulnerability, coping capacity and exposure indicators through the Delphi technique: A case study in Taquari-Antas basin, Brazil. Int J Disaster Risk Reduct 24:119-128. https://doi.org/10.1016/j.ijdrr.2017.05.027

Different natural disasters on a global scale (2016). Retrieved from https://emdat.be/

DSD. The Sustainability Report 2016-17 of Drainage Services Department. Retrieved from https:// www.dsd.gov.hk/Documents/SustainabilityReports/1617/en/sponge_city.html

Du S, Scussolini P, Ward PJ, Zhang M, Wen J, Wang L, Ke Q (2020) Hard or soft flood adaptation? Advantages of a hybrid strategy for Shanghai. Glob Environ Change 61:102037

Elboshy B, Kanae S, Gamaleldin M, Ayad H, Osaragi T, Elbarki W (2019) A framework for pluvial flood risk assessment in Alexandria considering the coping capacity. Environ Syst Decis 39(1):77-94

Faisal I, Kabir M, Nishat A (1999) Non-structural flood mitigation measures for Dhaka City. Urban Water 1(2):145-153

Fernandez P, Mourato S, Moreira M, Pereira L (2016) A new approach for computing a flood vulnerability index using cluster analysis. Phys Chem Earth, Parts A/B/C 94:47-55

Fleischhauer M (2008) The role of spatial planning in strengthening urban resilience. Resilience of cities to terrorist and other threats, pp 273-298. Springer

Fletcher TD, Shuster W, Hunt WF, Ashley R, Butler D, Arthur S, Bertrand-Krajewski J-L (2015) SUDS, LID, BMPs, WSUD and more-the evolution and application of terminology surrounding urban drainage. Urban Water J 12(7):525-542

Flood infographic: types, causes and cost of flooding (2016) Retrieved from https://www.fluvialinnovations.co.uk/2016/12/22/flood-infographic-types-causes-cost/

How can flooding be stopped? (2020) Retrieved from https://www.bbc.com/news/uk-25929644

InsulationCorp (2018) Green Roofs. Insulation Company of America. Retrieved from (https:// insulationcorp.com/green-roofs/)

Jha AK, Bloch R, Lamond J (2012) Cities and flooding: a guide to integrated urban flood risk management for the 21 st century. The World Bank

Jia H, Lu Y, Shaw LY, Chen Y (2012) Planning of LID-BMPs for urban runoff control: the case of Beijing Olympic Village. Sep Purif Technol 84:112-119

Jia H, Yao H, Tang Y, Shaw LY, Field R, Tafuri AN (2015) LID-BMPs planning for urban runoff control and the case study in China. J Environ Manage 149:65-76

Kang S-J, Lee S-J, Lee K-H (2009) A study on the implementation of non-structural measures to reduce urban flood damage. J Asian Archit Build Eng 8(2):385-392

Kaspersen PS, Ravn NH, Arnbjerg-Nielsen K, Madsen H, Drews M (2017) Comparison of the impacts of urban development and climate change on exposing European cities to pluvial flooding. Hydrol Earth Syst Sci 21(8):4131-4147

Len NLS, Bolong N, Roslee R, Tongkul F, Mirasa AK, Ayog JL (2018) Flood vulnerability of critical infrastructures-review. Malays J Geosci 2(1):31-34 
Liao K-H (2012) A theory on urban resilience to floods - a basis for alternative planning practices. Ecol Soc 17(4)

Mentens J, Raes D, Hermy M (2006) Green roofs as a tool for solving the rainwater runoff problem in the urbanized 21st century? Landscape Urban Plann 77(3):217-226

Mohamed WME (2019) Planning and Urban Policies and Mechanisms for Environmental Disasters. Environ Plann Infrast. Cairo. un published

Mojaddadi H, Pradhan B, Nampak H, Ahmad N, Ghazali AHB (2017) Ensemble machine-learning-based geospatial approach for flood risk assessment using multi-sensor remote-sensing data and GIS. Geomatics, Nat Hazards Risk 8(2):1080-1102

NEMO C (2018) How urbanization affects the water cycle. Retrieved from www.waterboards.ca.gov

Nguyen TT, Ngo HH, Guo W, Wang XC, Ren N, Li G, Liang H (2019) Implementation of a specific urban water management-Sponge City. Sci Total Environ 652:147-162

Psomiadis E, Dercas N, Dalezios NR, Spyropoulos NV (2016) The role of spatial and spectral resolution on the effectiveness of satellite-based vegetation indices. Paper presented at the Remote Sensing for Agriculture, Ecosystems, and Hydrology XVIII

Pyke CR, Andelman SJ (2007) Land use and land cover tools for climate adaptation. Clim Change 80(3-4):239-251

Rehan RM (2013) Sustainable streetscape as an effective tool in sustainable urban design. Hbrc J 9 (2): $173-186$

Saber M, Abdrabo KI, Habiba OM, Kantosh SA, Sumi T (2020) Impacts of triple factors on flash flood vulnerability in Egypt: urban growth, extreme climate, and mismanagement. Geosciences 10(1):24

Santato S, Bender S, Schaller M (2013) The European floods directive and opportunities offered by land use planning. CSC Report, 12

Schanze J (2006) Flood risk management —a basic framework. Flood risk management: hazards, vulnerability and mitigation measures, pp 1-20. Springer

Şen Z (2018) Flood modeling, prediction and mitigation. Springer

Shaw R, Colley M, Connell R (2007) Climate change adaptation by design: a guide for sustainable communities. Town and Country Planning Association

Sutanta H, Bishop I, Rajabifard A (2010) Integrating spatial planning and disaster risk reduction at the local level in the context of spatially enabled government

Tilley E (2014) Compendium of sanitation systems and technologies. Eawag

Types of Flooding in the UK (2018) Retrieved from https://www.cleansafeservices.co.uk/types-offlooding-in-the-uk/

Wheater H, Evans E (2009) Land use, water management and future flood risk. Land Use Policy 26:S251-S264

Brankovic MD, Protic IB. Bioswales as elements of green infrastructure-foreign practice and possibilities of use in the district of the City of Nis, Serbia

Hamburg: Hamburg University of Technology (TUHH) (n.d.) Detention and Retention Basins. Flood Manager. Retrieved from (http://daad.wb.tu-harburg.de/tutorial/integrated-floodmanagement-ifm-policy-and-planning-aspects/environmental-aspects/flood-management-interventions/ detention-and-retention-basins/)

Underground Storage. Retrieved from https://www.lakesuperiorstreams.org/stormwater/toolkit/ underground.html

Zevenbergen C, Bhattacharya B, Wahaab R, Elbarki W, Busker T, Rodriguez CS (2017) In the aftermath of the October 2015 alexandria flood challenges of an Arab city to deal with extreme rainfall storms. Nat Hazards 86(2):901-917

Zhang K, Chui TFM (2019) Linking hydrological and bioecological benefits of green infrastructures across spatial scales - a literature review. Sci Total Environ 646:1219-1231

Zhang J, Hori T, Tatano H, Okada N, Zhang C, Matsumoto T (2003) GIS and flood inundation model-based flood risk assessment in urbanized floodplain. Paper presented at the Proceedings of the International Conference of GIS and Remote Sensing in Hydrology 
Open Access This chapter is licensed under the terms of the Creative Commons Attribution 4.0 International License (http://creativecommons.org/licenses/by/4.0/), which permits use, sharing, adaptation, distribution and reproduction in any medium or format, as long as you give appropriate credit to the original author(s) and the source, provide a link to the Creative Commons license and indicate if changes were made.

The images or other third party material in this chapter are included in the chapter's Creative Commons license, unless indicated otherwise in a credit line to the material. If material is not included in the chapter's Creative Commons license and your intended use is not permitted by statutory regulation or exceeds the permitted use, you will need to obtain permission directly from the copyright holder.

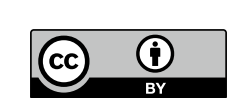

